\title{
Total diz protezinde cerrahi teknikler ve temel prensipler
}

\author{
Surgical techniques and main principles in total knee arthroplasty
}

\author{
Ömer Yonga ${ }^{1}$, Barış Kadıŏlu², Melih Güven² \\ 'T.C. Sağlık Bakanlığı Tuzla Devlet Hastanesi, Ortopedi ve Travmatoloji Kliniği, İstanbul, Türkiye \\ ${ }^{2}$ Ataşehir Florence Nightingale Hastanesi, Ortopedi ve Travmatoloji Kliniği, İstanbul, Türkiye
}

\begin{abstract}
Total diz protezi cerrahisinin birincil amacı, ağrının giderilmesi ve diz eklem fonksiyonunun mümkün olduğunca eski haline getirilmesidir. Cerrahi teknikler yüksek düzeyde hassasiyet gerektirir. Uygun olmayan cerrahi teknikler ve bunlara bağlı gelişebilecek komplikasyonlar protezin uzun dönem sağkalımını olumsuz olarak etkiler. Başarılı bir girişim için, cerrah diz eklem anatomisini ve biyomekanik özelliklerini yeterince bilmeli, cerrahi teknikleri bu bilgilere bağlı kalarak uygun şekilde uygulayabilmelidir. Diz protezi cerrahisi birbiriyle iliş̧kili ardışık adımlardan oluşmaktadır. Bir sonraki adımda sıkıntı yaşanmaması için bir önceki adımın eksiksiz gerçekleştirilmesi gerekir.

Anahtar sözcükler: diz; total diz protezi; cerrahi teknikler
\end{abstract}

The primary goal of total knee replacement surgery is to relieve pain and restore knee joint function as much as possible. Surgical techniques require a high level of precision. Inappropriate surgical techniques and related complications adversely affect the long-term survival of the prosthesis. For a successful intervention, the surgeon should know enough about the anatomy and biomechanical features of the knee joint; and apply surgical techniques appropriately by adhering to this information. Knee replacement surgery consists of interrelated sequential steps. The previous step must be performed completely so that there is no problem in the next step.

Key words: knee; total knee arthroplasty; surgical techniques
T otal diz protezinde (TDP) temel amaçlar ağrıyı ortadan kaldırmak, eklem hareket genişliğini artırmak ve fonksiyonel düzeyde iyileşme sağlamaktır. Bu amaçlara ulaşabilmek için TDP'de cerrahi teknikler dikkat, özen ve yüksek hassasiyet gerektirir. Uygun olmayan cerrahi teknikler ve bunlara bağlı gelişebilecek komplikasyonlar, TDP cerrahisinin uzun dönem sağkalımını olumsuz olarak etkiler. Başarılı bir operasyon için cerrahın diz eklem anatomisi ve biyomekaniği ile ilgili yeterli bilgiye sahip olması ve bu bilgiler ışığında doğru cerrahi teknikleri uygulaması gerekir. Cerrahın deneyiminin yanı sıra kullanılacak implantlar hakkında da bilgi sahibi olması önemlidir. Ayrıca ameliyathane ortamında sağlık personeli ile uyumlu ekip çalışması TDP cerrahisinde başarıyı artıran önemli faktörlerdendir. ${ }^{[1]}$

Operasyon, birbiriyle ilişkili ardışık adımlardan (cerrahi hazırlık ve örtüm, cerrahi kesi ve yaklaşım, yumuşak dokulara yönelik girişimler ve gevşetme, kemik kesileri, fleksiyon ve ekstansiyon aralıklarının dengelenmesi, komponentlerin yerleştirilmesi ve kapatma) oluşmaktadır. Bir sonraki adımda sıkıntıların yaşanmaması bir önceki adımın eksiksiz gerçekleşmesi ile mümkündür.

\section{CERRAHI HAZIRLIK VE ÖRTÜM}

Öncelikle, tek taraflı cerrahi uygulanacak ise girişim öncesinde mutlaka ekstremite işaretlemesi yapılmalıdır. Supin (sırt üstü) pozisyonda gerçekleştirilen TDP cerrahisinde ameliyat masasına yerleştirilen rulo ve yan destekler ile cerrahi uygulamayı kolaylaştıracak pozisyonlar test edilmelidir (Şekil 1). Turnike mümkün olduğunca uyluk proksimaline ve distale kaymayacak şekilde yerleştirilmelidir. Betadine veya scrub solüsyonları ile ayak parmakları dâhil olacak şekilde uzuv temizlenmelidir. Kurulamadan sonra ayak dâhil cerrahi boyama yapılır ve örtüm işlemine geçilir. Örtüm, cerrahi enfeksiyonu önlemenin ilk adımıdır ve diz eklem hareket açıklığına engel olmayacak şekilde yapılmalıdır. Örtüm ardından açıkta cilt kalmayacak şekilde yapışkan cerrahi örtü (drape) uygulaması gerçekleştirilir. Eğer tibial taraf kemik kesisi için

iletişim / Contact: Prof. Dr. Melih Güven • E-posta / E-mail: maguven2000@gmail.com

ORCID iD: Ömer Yonga, 0000-0002-3872-8836 • Barış Kadıŏlu, 0000-0001-9631-8483 • Melih Güven, 0000-0002-9656-1608 

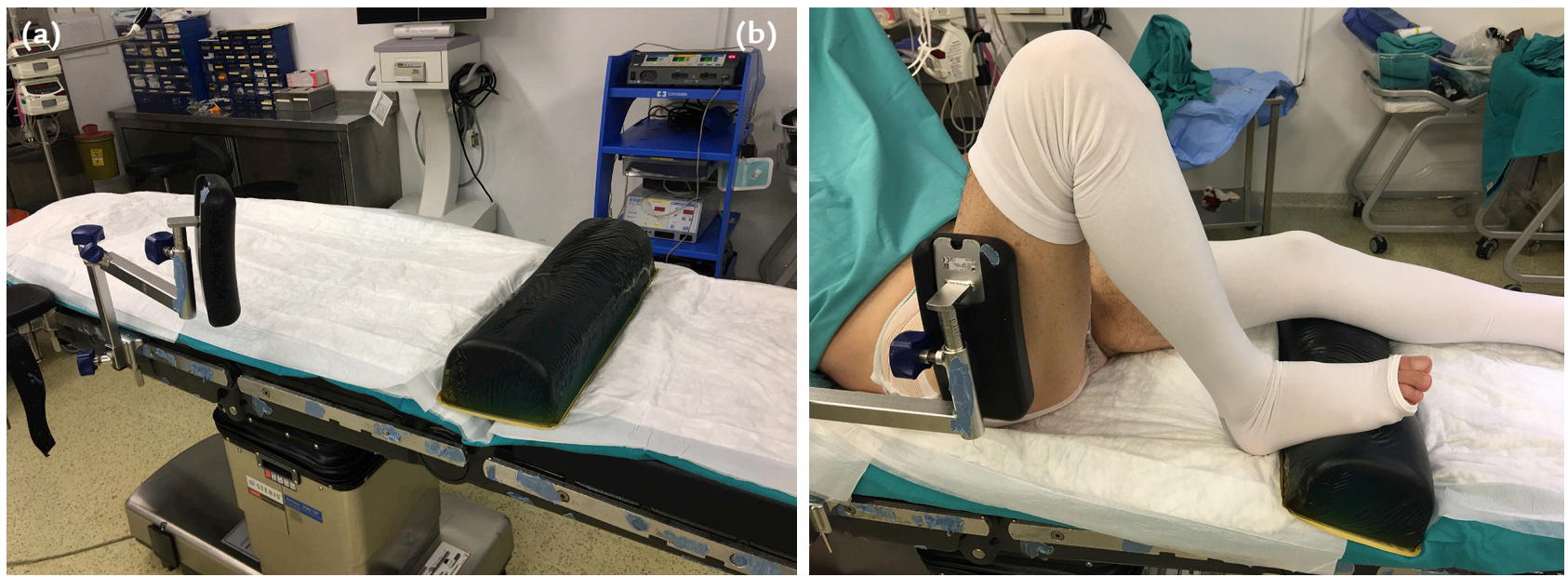

Şekil 1. a, b. TDP cerrahisinde hastanın ameliyat masasındaki pozisyonunu kolaylaştırmak amacıyla yerleştirilen yan destek ve rulolar (a). Hasta pozisyonunun cerrahi öncesi kontrolü (b).

ekstramedüller kılavuz sistemi kullanılacak ise ayak ve ayak bileğinin görülmesine izin verecek şekilde örtüm gerçekleştirilmelidir. Operasyon masası su geçirmez bir örtü ile örtülmelidir (Şekil 2). ${ }^{[2]}$

Primer olgularda çok ihtiyaç duyulmamakla birlikte revizyon olgularında $\mathrm{C}$ kollu skopi ile uyumlu ışın geçirgen operasyon masası mevcut olmalıdır. Diz, dış rotasyon eğilimi gösterdiğinden, ameliyat masasına ameliyat edilecek diz patellası tavanı gösterecek şekilde eğim verilebilir. Operasyona katılan herkes kontaminasyonu önlemek ve kendisini korumak amaçlı çift kat eldiven

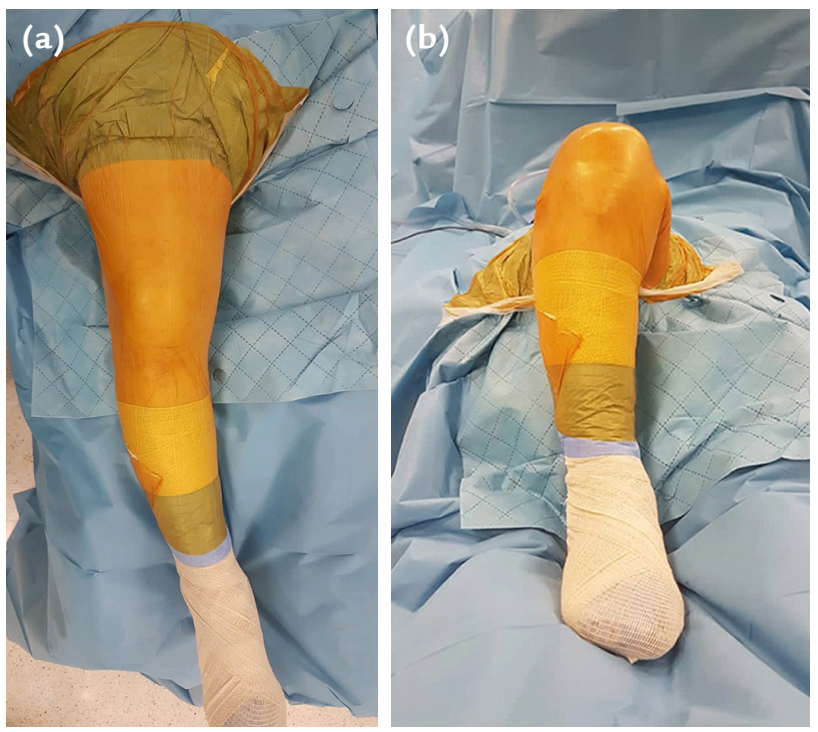

Şekil 2. a, b. Ekstremitenin cerrahi örtüm sonrası ameliyat masasındaki üstten (a) ve önden (b) görüntüsü. giymelidir. Ayrıca bulaşıı hastalığı olan hastalar üzerinde çalışırken koruyucu gözlük veya vücut tulumu gereklidir. Turnike uygulamasında ameliyat edilecek uzvun venöz drenajı için steril Esmarch bandajı veya elastik bandaj kullanılabilir. Turnike şişirilmeden önce dizi fleksiyona getirmek ekstansör mekanizmayı uzatacağı için ameliyatın ilerleyen evrelerinde patellanın dışa devrilmesini kolaylaştıracaktır. Ayrıca intravenöz antibiyotik profilaksisinin de mutlaka turnike öncesi yapılmış olması gerekir. Ekstremite eleve edildikten sonra turnike basıncı sistolik kan basıncının en az $100 \mathrm{mmHg}$ fazlasına veya onun iki katı olacak değere ayarlanmalıdır. Doksan dakikadan fazla süren operasyonlarda turnikeyi serbest bırakmak ve yeniden şişirmek güvenlidir. ${ }^{[3]}$ Turnike kullanımı ile kanama azaltılarak cerrahın operasyonu daha doğru ve daha hızlı yapması sağlanır. Kanamasız ve iyi bir operasyon alanı sağlanması daha dayanıklı çimento tespitini güvence altına alacaktır. Turnike kullanımında kan basıncında geçici artışla birlikte kardiyovasküler aşırı yüklenme, pulmoner ödem ve kalp yetmezliği gelişimi riski dışında ameliyat edilen ekstremitedeki uzamış iskemiye bağlı gelişebilecek komplikasyonlar göz önünde bulundurulmalıdır. Bu nedenle, kardiyovasküler hastalığı veya periferik damar problemi olan hastalarda turnike kullanılırken dikkatli olunmalıdır.

\section{CERRAHI KESI VE YAKLAŞIM}

İyi bir cerrahi yaklaşım; yeterli bir açılım sağlamalı, damar-sinir yapılarını korumalı, protezin işlevine uygun olmalı ve cerraha kolaylık sağlamalıdır. TDP cerrahisinde cilt kesisi ve yaklaşım sırasında yapılacak hatalar cerrahi süreyi uzatabileceği gibi ameliyatın diğer aşamalarını da olumsuz etkiler. Kötü bir cerrahi 
yaklaşım, geçirilmiş diz cerrahisi veya cilt sorunları olan hastalarda cilt ve derin doku nekrozuna sebep olabilir. Herhangi bir cilt veya yumuşak doku sorunu gelişirse iyileşme gecikir ve prognoz kötüleşir. ${ }^{[4]}$

Total diz protezinde tüm önemli sinir ve damar yapılarının diz arkasında bulunması nedeniyle anterior yaklaşım benimsenmiştir. Cerrahi yaklaşımlar; cilt kesisi, artrotomiler ve ekstansör mekanizma için yardımcı yöntemler (genişletilmiş yaklaşımlar) olmak üzere üç ana başlık altında incelenebilir.

\section{Damar-Sinir Anatomisi ve Cilt Kesisinde Temel Prensipler}

Total diz protezinde iyi bir yara iyileşmesi sağlamak için cilt kesisi düzgün ve pürüzsüz olmalıdır. Sağlıklı cilt iyileşmesi için damarlanmanın iyi bilinmesi gerekir. Bu bölgenin dolaşımı ekstrinsik arterler ve patellanın etrafinda halka oluşturan intrinsik arterlerden kaynaklanır. Ekstrinsik arterler, cilt altı tabakada bulunur ve safen arter, desendan geniküler arter ve medialden gelen musküler dalları içerir. İntrinsik arterler ise fasya altı tabakada bulunur ve patellanın etrafında halka yapısı oluşturan medial superior geniküler, medial inferior geniküler, lateral superior geniküler, lateral inferior geniküler ve anterior tibial tekrarlayıcı arterlerden oluşur. ${ }^{[5]}$ Yara iyileşmesinde çoğunlukla ekstrinsik arterler etkilidir. Yüzeyel tabakadaki damarlar ile derin yerleşimli olanlar perforan arterlerle bağlantı halindedir. Bu dolaşım özelliği nedeniyle normalden daha medialden yapılan insizyonlarda, lateralde daha fazla dolaşım problemi görülme riski artar. ${ }^{[6]}$ Derin fasyanın çok fazla disseksiyonu da, perforan arterleri tehlikeye atarak yara iyileşme problemine neden olabilir. Bu nedenle cilt insizyonu mümkün olduğunca medialden uzak yapılmalı ve insizyonun lateralinde çok fazla cilt altı doku disseksiyonundan kaçınılmalıdır.

Uyluğun ön kısmında medial ve orta kutanöz sinir, medialden lateral tarafa doğru uzanır ve uyluğun ön alanını innerve eder. Tibial tarafta ise safen sinirin infrapatellar dalı medialden laterale doğru uzanır. Ĕger cilt kesisi çok proksimale uzanırsa medial ve orta kutanöz sinirin yaralanma ihtimali artar.

Ameliyat sonrası erken dönemde yara iyileşme problemi gelişirse, cerrahi kesi ekleme çok yakın olduğundan derin enfeksiyon gelişme riski artar. Bu durum rehabilitasyon programını ve ameliyat sonucunu olumsuz etkiler. Bu nedenle cerrahi cilt kesisinde temel prensiplere uymak gerekir. TDP'de cilt kesisi dikey ve doğrusal olarak yapılır. Yaşlılarda, retraksiyon esnasında cilt gerginliğini azaltmak ve nekrozu önlemek için cilt kesisi mümkün olduğunca uzun olmalıdır. Cilt kesisi, geçirilmiş diz ameliyatı ve ciddi deformitesi olan hastalarda farklılık gösterebilir. Geçirilmiş diz cerrahisi

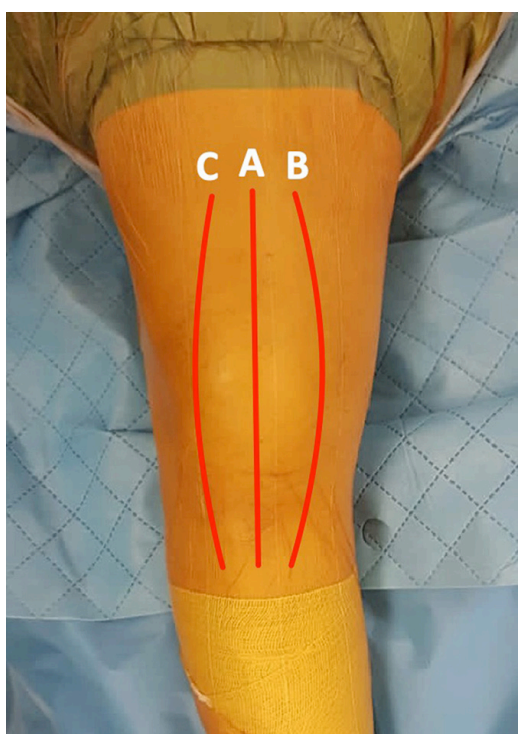

Şekil 3. TDP cerrahisinde kullanılabilecek cilt kesileri (A, orta hat (midline) cilt kesisi; $\mathrm{B}$, paramedial cilt kesisi; $\mathrm{C}$, lateral cilt kesisi).

öyküsü olan hastalarda küçük transvers insizyon skarları ile artroskopi portalleri, yeni insizyon ile dikey olarak geçilebilir ve yara problemleri oluşmayabilir. Yeni cilt insizyonlarının, eski insizyon hatları ile geniş açıyla kesişmesi istenir. Eski insizyon büyük ebatlı ise yeni insizyonun onun üzerinden yapılması daha uygun olacaktır. Eğer eski insizyon yeterli değil ve yeni bir insizyon yapılacaksa daha lateralden yapılması tercih edilir. Ancak yeni kesi ile eskisi arasındaki mesafe en az $7 \mathrm{~cm}$ olmalıdır. Yakın zamanda popülaritesi artan minimal invaziv cerrahi, önemli cilt problemleri olmayan hastalarda uygulanmalıdır. ${ }^{[7]}$

\section{Cilt Kesisi Tipleri}

Total diz protezi cerrahisinde uygulanabilecek cilt kesileri üç başlık altında toplanabilir (Şekil 3).

\section{Orta hat (midline) cilt kesisi}

En yaygın kullanılan cilt kesisidir. Diz ekleminin merkezinde olacak şekilde yaklaşık 12-14 cm uzunluğunda düz bir kesi yapılır. Kesi patellanın $4-5 \mathrm{~cm}$ proksimalinden başlar ve tibial tüberkülün yaklaşı $1 \mathrm{~cm}$ distal ve medialinde sona erer (Şekil 4). Kesi, tibial tüberkülün üzerinden yapılırsa, ağıı ve yara iyileşmesi sorunlarıyla karşılaşılabilir. Kesinin distali tüberositas tibiayı en az $1 \mathrm{~cm}$ geçmelidir, çünkü bu bölgede cilt incedir ve damarlanması zayıftır. Orta hat keside paramedial kesiye kıyasla kanlanma daha az zarar görür. Aynı zamanda herhangi bir artrotomi bu yolla yapılabileceği gibi revizyon cerrahisinde bu kesi proksimal ve distale rahatlıkla 

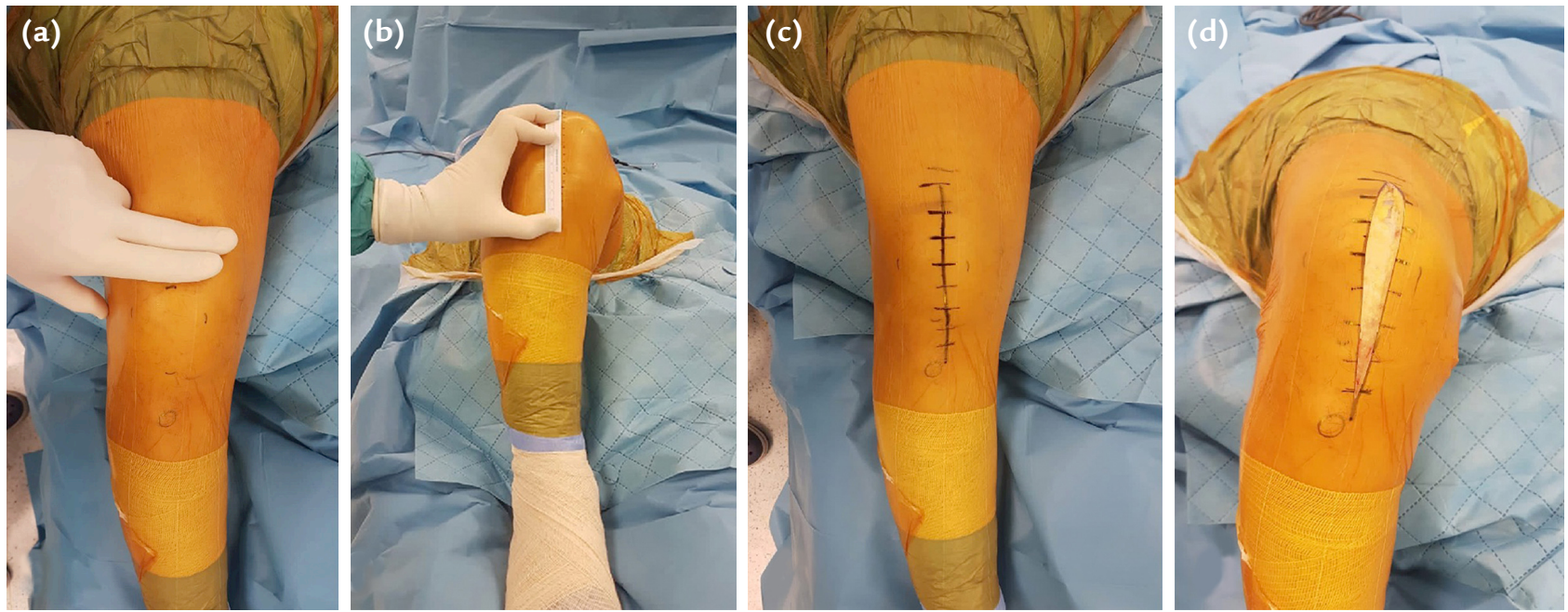

Şekil 4. a-d. Patellanın üst kutbuna yerleştirilecek iki parmak ile cilt kesisinin üst ucunun belirlenmesi (a). Steril bir cetvel yardımıyla total cilt uzunluğunun belirlenmesi (b). Cilt kesisi öncesi işaretleme (c). Orta hat (midline) cilt kesisi (d).

uzatılabilir. ${ }^{[8]}$ Orta hat cilt kesisini diz fleksiyonda iken yapmak cilt altı dokunun mediale ve laterale kaçmasını sağlar ve açılımı kolaylaştırır. Diz ekleminde daha önceki girişimlere ait anterior eski bir kesi varsa, yeni kesi bu kesi ile eğer birden çok eski kesi varsa en lateraldeki ile birleştirilir. Çünkü cildin kan dolaşımı baskın olarak medialden gerçekleşmektedir.

\section{Paramedial cilt kesisi}

Eskiden çok yaygın kullanıımıştır. Merkezi patellanın medialinden geçen kavisli cilt kesisinin, proksimal ve distal uçları orta hat kesi ile aynı veya onun biraz medialindedir. Patellanın lateralinde aşırı cilt altı doku disseksiyonuna bağlı beslenme problemlerinin görülmesi üzerine kullanım sıklığı azalmıştır. Ayrıca, bu kesinin revizyon TDP'de kullanılması zor olabilir. Bu nedenlerle sadece istisnai durumlarda kullanılır.

\section{Lateral cilt kesisi}

$\mathrm{Bu}$ keside merkez patellanın lateral kenarında yer almaktadır. Lateral kesi damarsal dolaşımı daha fazla korur, ancak daha kısıtlı açılım sağlar. Daha iyi bir açıım için artrotominin de lateralden yapılması gereklidir. Bunun yanı sıra, orta hat kesiye alışkın cerrahlarda uyum (oryantasyon) sorunlarına neden olabilir. Bu nedenle, bu kesi istisnai olarak valgus deformitesi olan hastalarda kullanılmaktadır.

\section{Artrotomi}

Cilt kesisinin ardından ekleme ulaşmak için gerçekleştirilen artrotomi işleminde patella çevresindeki kan dolaşımının bilinmesi önemlidir. İntrinsik arterler patellanın etrafında halka şeklinde bir yapı oluştururlar. Bu damarsal yapı nedeniyle artrotomi yöntemleri çeşitlilik göstermektedir. Medial taraf için paramedial (medial parapatellar), subvastus, midvastus ve medial trivektör koruyan artrotomi yöntemleri ile lateral taraf için lateral (lateral parapatellar) artrotomi yöntemi tanımlanmıştır.

\section{Paramedial (medial parapatellar) artrotomi}

Paramedial artrotomi iyi açılım sağladığından ve istenildiğinde proksimale uzatılabildiğinden en sık kullanılan artrotomi yöntemidir (Şekil 5). ${ }^{[9]}$ Proksimalde kuadriseps tendonu uzunlamasına merkezinden, medial
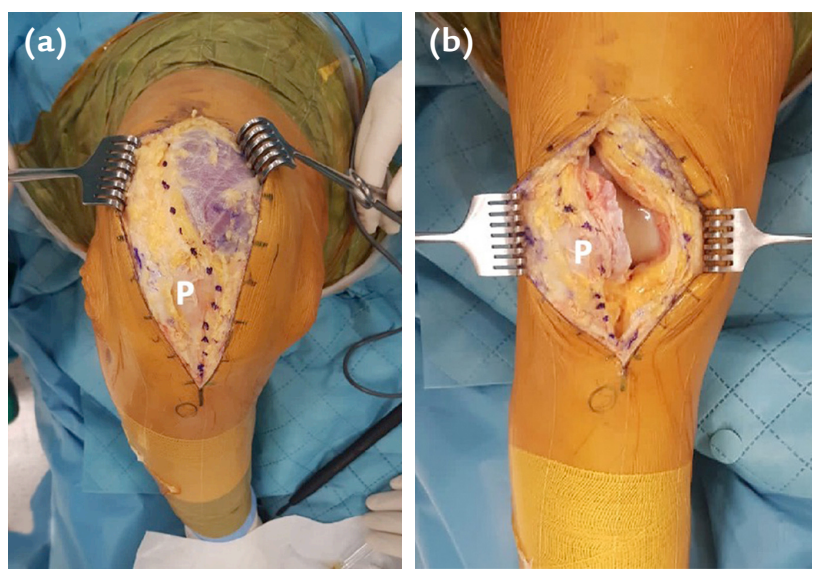

Şekil 5. a, b. Paramedial (medial parapatellar) artrotomi hattı (a). Artrotomi sonrası görünüm (b) ( $P$, patella). 
1/3'ünden veya kas-tendon bileşkesinden kesilebilir. Tendonun medial 1/3'ünden uygulanan kesi kas-tendon sınırından yapılan kesiye kıyasla daha az kanamaya ve fibrozis gelişimine neden olduğundan sıklıkla tercih edilir. Aslında kuadriseps tendonunun genişliği her hastada farklılık gösterir. Buna bağlı olarak tendonun genişliğine göre kesi daha lateralden veya medialden başlatılabilir. Insall ve Easley, patellar bölgede tendonun sıyrılmasını önlemek için ekstansör mekanizmaya paralel kesi yapılmasını önermişlerdir. ${ }^{[7]}$ Çoğu cerrah kesi tercihini kapsülün kolayca kapatılabilmesi için patellanın $5 \mathrm{~mm}$ medialinden geçecek şekilde uygulamaktadır. Tibial kesimde ise kesi, patellar tendonun korunması amacıyla, mümkün olduğunca tibial tüberkülün medialinde sonlanmalıdır. En sık tercih edilen yöntem olmasına karşın bu artrotominin ameliyat sonrası ekstansör mekanizmada ve medial damarlanmada zayıflama gibi dezavantajları da mevcuttur. Artrotomi sonrası patella laterale devrilip diz fleksiyona alınırken patellar tendonun tüberositas tibiaya yapışma yerinden avülse edilmemesine dikkat edilmelidir.

\section{Subvastus artrotomi}

Vastus medialis, medial intermusküler septumdan künt disseksiyonla ayrilır. Bu artrotomi, adduktor tüberkülün $10 \mathrm{~cm}$ proksimalinde yer alan, patellanın superomedial kısmından başlayıp intermusküler septuma, distalde ise tibial tüberkülün medialine kadar uzanan $L$ şeklinde bir artrotomidir (Şekil 6). ${ }^{[10]} \mathrm{Bu}$ yaklaşımda sıklıkla patella dışa devrilmez, onun yerine laterale retrakte edilir. Bu yöntemde, ekstansör mekanizma kesilmez ve medial superior geniküler arter korunur. ${ }^{[11]}$ Kuadriseps tendonunun kesildiği artrotomilerde ise, kas gücü zayıflaması ve patellanın lateral subluksasyon riskinde artış söz konusu olabilmektedir. ${ }^{[2]}$ Patellanın laterale devrilmemesi de kas gücünün erken restorasyonu için oldukça yararlıdır. Ancak uzun dönem takiplerde bu artrotominin kas gücü açısından diğerlerinden üstünlüğü gösterilememiştir. Yetersiz cerrahi açılım sağlaması ve ameliyat sonrası ağıı artışı bu artrotominin dezavantajlarındandır. Ayrıca aşırı retraksiyon uygulanmasına bağlı vastus medialis kas gücü zayıflığı ile kas içi hematom oluşumu da söz konusu olabilir. ${ }^{[12]}$ Obez, kaslı, geçirilmiş diz cerrahisi öyküsü olan hastalar ile ankiloz veya deformitesi olan hastalarda yetersiz cerrahi açılım sağlayacağından subvastus artrotomisi tercih edilmemelidir.

\section{Midvastus artrotomi}

$\mathrm{Bu}$ artrotomi, patellanın superomedial kısmının 4-5 cm kadar proksimalinde vastus medialis kasını merkezleyecek şekilde başlar ve distalde medial eklem kapsülüne kadar ilerler (Şekil 6). Daha distalde ise patellar tendonun medial $1 / 4$ 'lük kısmını içererek sonlanır. Patella laterale devrilebilir ya da retrakte edilebilir. ${ }^{[13]}$ Bu yöntemin avantajı, patellanın proksimal kısmındaki kuadriseps tendonunu ve vastus medialis kasının yarısını korumasıdır. Böylelikle patellanın kan akımı ile ekstansör mekanizmanın daha çok korunması hedeflenir. Vastus medialis kası, femoral sinirin bir dalı olan safen sinir tarafindan inerve edilir. Bu sinir, vastus medialis kasının başlangıcına yakın bir yerde kasa giriş yaptığı için bu artrotomide zarar görmesi beklenmez. Ayrıca, superior geniküler arterin iki dalından proksimalde olanı desendan geniküler arter ile anastomoz yaptığı için kan akımı göreceli olarak korunmuş olur.

Midvastus artrotomisi, patellanın tam olarak retraksiyonuna veya laterale devrilmesine izin verir ve istenirse rektus snip kesisine çevrilebilir. Obez veya daha önce diz revizyonu uygulanan hastalarda dizin $90^{\circ}$ 'den fazla fleksiyonuna olanak sağlar. Paramedial artrotomiye göre lateral retinaküler dokuda gevşeme ihtimali daha düşüktür ve ameliyat sonrası ilk altı ayda ağrı ve kas gücü düzeyi paramedial artrotomi olgularındakine benzerdir. ${ }^{[13]}$

\section{Medial trivektör koruyan artrotomi}

TDP'nin en yaygın komplikasyonlarında birisi anormal patellar yerleşimdir. Bu artrotominin mantığı kuadriseps kas dengesizliğine bağlı gelişebilecek kötü patellar yerleşimi engellemektir. Artrotomi kesisi kuadriseps vektörünün merkezinden geçerse, kuadriseps

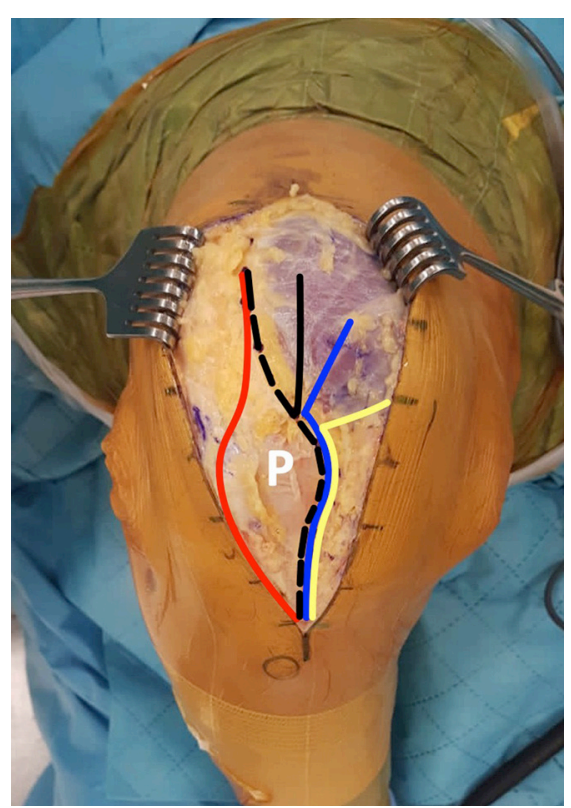

Şekil 6. Subvastus (sarı çizgi), midvastus (mavi çizgi), medial trivektör koruyan (siyah çizgi) ve lateral (kırmızı çizgi) artrotomi hatları (P, patella; kesikli siyah çizgi, medial parapatellar artrotomi hattı). 
tendonunu doğal olarak stabilize eden kuvvetler dengelenir ve bu da patellar yerleşimi normalize eder. Kuadriseps kas vektörü merkezi, vastus medialis kasının yaklaşık 1,5-2 cm medialindedir. Bu artrotomide vastus medialis kası, kuadriseps tendonunun yaklaşı $1,5-2 \mathrm{~cm}$ medialinden vertikal olarak kesilir. Kesi, vastus medialis kasının intrinsik kararlılı̆ını korumak için distalde tibial tüberkülün $1 \mathrm{~cm}$ medialine kadar uzatılır (Şekil 6). ${ }^{[14]}$ Bu yöntem, anatomik olarak paramedial artrotomiye ve biyomekanik olarak midvastus artrotomisine benzemektedir. Dezavantajları, medialden kan akımının kesintiye uğraması ve vastus medialis kasının kesilmesidir.

\section{Lateral artrotomi}

$\mathrm{Bu}$ artrotomi patellanın lateral tarafindan eklemin açılmasını sağlar. İstisnai olarak valgus deformitesi olan hastalarda kullanılır. Cilt insizyonu, Q açısını takiben kuadriseps tendonu, patella ve patellar tendonun lateral tarafından yapılır ve tibial tüberkülün 1-2 cm lateralinde olan Gerdy tüberkülünün medial kenarında sona erer (Şekil 6). Bununla birlikte tibial tüberkülün lateralinde biten standart bir orta hat kesi de kullanılabilir. ${ }^{[15]}$ Valgus deformitesi olan hastalarda paramedial artrotomi yapıldığında, tibianın mevcut dış rotasyon deformitesi artabilir ve patellar yerleşim sorunu ortaya çıkabilir. Ayrıca, valgus deformitesinde lateral yapılara yaklaşmak paramedial artrotomi ile zordur ve lateral retinaküler bağın gevşetilmesi gerekebilir. Bu da operasyon sırasında hem medial, hem de lateral taraftan dolaşım bozukluğu riskini artırır. Valgus deformitesi olan dizlerde tercih edilen lateral artrotomi ile diz ekleminin lateral kompartmanına ve posterolateral eklem mesafesine ulaşım daha kolaydır. Medial retinakulum sağlam kaldığından patellofemoral uyum daha sorunsuzdur. Ayrıca aşırı fleksiyon kontraktürü ve eksternal tibial torsiyon deformitesinde daha iyi bir düzeltme imkânı sağlar.

$\mathrm{Bu}$ artrotominin avantajları; deforme olmuş bölgeye doğrudan yaklaşılmasına izin vermesi, kan akımının korunmasına yardımcı olması ve artrotomi sırasında lateral retinaküler bağın gevşetilmesine izin vermesidir. Diğer avantajları cilt altı disseksiyonunu azaltarak daha az doku beslenme problemine yol açması ve yumuşak dokuların kademeli olarak gevşetilebilmesine izin vermesidir. Dezavantajları, medial tarafta iyi bir operasyonel açılım sağlamaması, patellanın dışa devrilmesini zorlaştırması, medial yaklaşıma alışkın cerrahlar için oryantasyon sorunu, fibuler sinir yaralanma ihtimali ve lateralde tamiri mümkün olmayan yumuşak doku defektleri yaratabilmesidir. Diğer bir deyişle, valgus deformitesini düzeltmek ve lateral taraftaki yumuşak doku kontraktürünü doğal olarak gevşetmek için tercih edilebilecek bir yöntem olan lateral artrotomi, bu konuda az deneyime sahip cerrahlar tarafından uygulandığında daha fazla soruna neden olabilir.

\section{Ekstansör Mekanizma için Yardımcı Yöntemler (Genişletilmiş Yaklaşımlar)}

Ciddi deformiteli olgularda, kuadriseps kontraktürüne bağlı eklem hareket kısıtlılığı durumlarında ve standart girişimlerle yeterli cerrahi açıım sağlanamayan revizyon diz protezi olgularında ekstansör mekanizma için yardımcı yöntemler artrotomi yaklaşımı için kullanılır.

Patellanın dışa devrilmesi veya retraksiyonu mümkün olmadığında ilk adım kesiyi proksimale uzatmak ve ardından lateral patellofemoral ligamenti ve lateral eklem kapsülünü kesmek veya lateral retinaküler ligamenti serbestleştirmektir. Bu yöntemlere rağmen patella dışa devrilemez ya da retrakte edilemez ise, ekstansör mekanizmanın zarar görmesini engellemek amacıyla bazı yardımcı genişletilmiş yöntemler devreye girmektedir. Alternatif olarak, zor olgularda yardımcı yöntemler en baştan da uygulanabilir. Ekstansör mekanizma için yardımcı yöntemler; rektus snip, V-Y kuadrisepsplasti ve tibia tüberkül osteotomisidir. ${ }^{[16-18]} \mathrm{Bu}$ yöntemler kendi içinde karşılaştırıldığında rektus snip tekniğinin daha iyi sonuçlara ve daha düşük morbiditeye sahip olduğu, bu nedenle de olguların çoğunda bu yöntemin tercih edildiği bildirilmektedir. ${ }^{[16]}$

\section{Rektus snip}

Rektus snip yöntemi, rektus femorisin kas-tendon bileşkesinden kesilmesini içerir. Bu yöntemin yararı basit olması, vastus medialis kasının bütünlügüunü ve superior geniküler arteri korumasıdır. Bu nedenle ameliyat sonrası ekstansiyon kısıtlılığı nadiren ortaya çıkar. Rektus snip, revizyon veya ankilozlu dizde ekstansör mekanizma için en mütevazi ve koruyucu yöntemdir. Kuadriseps tendonu, medial artrotominin proksimal ucundan superolaterale doğru $45^{\circ}$ açıyla kesilir (Şekil 7). Ancak medial kesinin seviyesine göre inferolaterale veya lateral artrotomide lateral taraftan superomediale uzatılabilir. Yeterli açılım için rektus snip yeterli değilse, kesi distal tarafta laterale uzatılabilir. ${ }^{[16]}$ Lateral retinaküler gevşetme, superior geniküler arteri korumak için rektus snip ile birlikte uygulanabilir. Rektus snip sonrası ameliyat sonrası üç hafta boyunca ekstremitenin ekstansiyonda immobilizasyonu gerekebilir.

\section{V-Y kuadrisepsplasti}

V-Y kuadrisepsplasti ekstansör mekanizmanın boyunun uzamasını sağlayan bir yöntemdir (Şekil 8). ${ }^{[17]} \mathrm{Bu}$ yöntem kuadriseps tendonu üzerinden yapılan kesilerin 


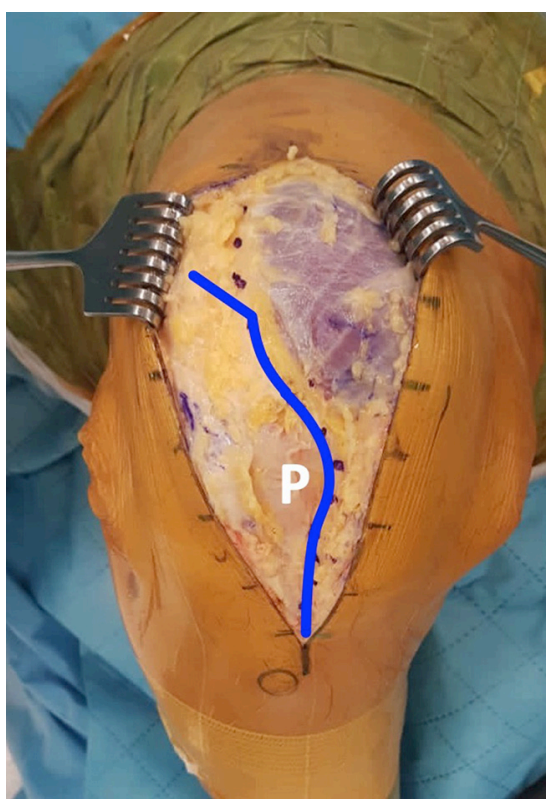

Şekil 7. Rektus snip artrotomi hattı (P, patella).

şekline göre alt tiplere ayrilır. Z-plasti ise kuadriseps tendonunu uzatmak için yapılan başka bir kesi şeklidir. Hem V-Y kuadrisepsplasti, hem de Z-plasti iyi bir cerrahi açılım sağlar. Ancak tendonu daha güvenli ve kademeli uzattığı için V-Y kuadrisepsplasti daha çok tercih edilen yöntemdir. Rektus snip sonrası patellanın dışa devrilmesinin mümkün olmadığı durumlarda V-Y kuadrisepsplasti uygulanabilir. Patellar kan akımının bozulmasıyla avasküler nekroz riskinin artması, kuadriseps kasının gücünün zayıflaması ve buna bağıı olarak diz ekstansiyon gücünün azalması V-Y kuadrisepsplastinin dezavantajlarıdır. Bu nedenle allogreft ile güçlendirme ihtiyacı olmaması için ekstansör mekanizmada çok fazla uzatma tavsiye edilmez. V-Y kuadrisepsplastide onarım titizlikle yapılmalıdır. Ameliyat sonrası dönemde eklem hareket açıklığı egzersizleri yaklaşık 6-8 hafta kısıtlanmalıdır.

\section{Tibial tüberkül osteotomisi}

Ciddi kuadriseps tendon kontraktürü veya fibrotik ankilozu olan hastalarda kullanımı önerilmektedir. Çok iyi bir açılım sağlaması, tibial tüberkülün istenilen yere konumlandırılıp kaydırılabilmesi ve revizyon cerrahisinde tibial komponentin daha kolay çıkarılabilmesi bu yöntemin avantajlarındandır. ${ }^{[18]}$ Bu yöntemde kemik-kemik iyileşmesi olacağından kuadriseps kas gücü daha iyi korunur ve erken rehabilitasyona izin verir. Ameliyat sonrası ağrı, osteotomi hattında kaynamama, fragman kırılması, patellar tendon rüptürü, enfeksiyon ve yöntemin zaman alıcı olması dezavantajlar

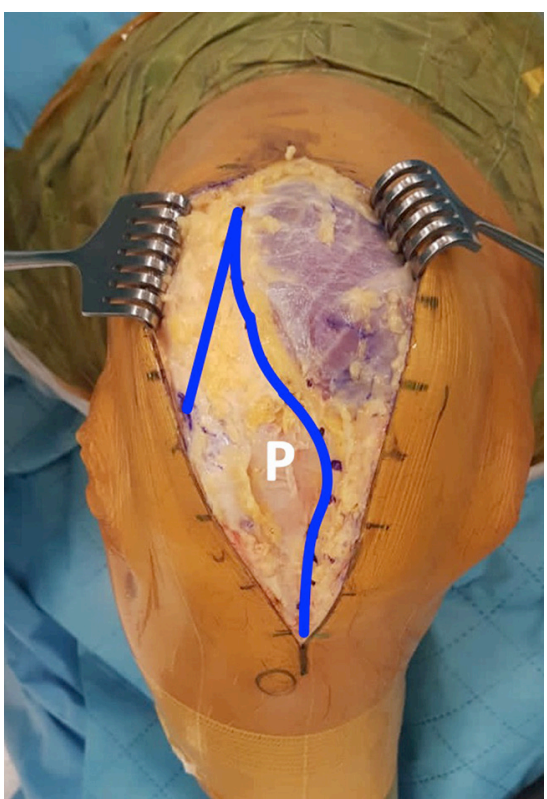

Şekil 8. V-Y kuadrisepsplasti artrotomi hattı (P, patella).

olarak sıralanabilir. Osteotomi sonrası kemik parçası yaklaşık $5 \mathrm{~cm}$ uzunluğunda, $2 \mathrm{~cm}$ genişliğinde ve en az $1 \mathrm{~cm}$ kalınlığında olmalıdır. Parçanın kırılma olasıIı̆̆ını azaltmak için distal kısmı daha eğimli hazırlanabilir. Osteotomi sırasında parçanın kan akımının korunması önemlidir. Bunun için lateral taraftan periost bağlantısı ayrılmamalıdır. ${ }^{[19]}$ Vida ile tespit sırasında kemik parçada parçalanma oluşabilir. Bu durumda serklaj teli tespiti (üç adet) kullanılması önerilmektedir. Kullanılacak tellerden en üstteki kaymayı önleyici şekilde konumlandırılmalı, diğer ikisi ise kompresyona yardımcı olmalıdır. Osteotomi yapmadan önce tespit delikleri hazırlanmalıdır. Ameliyat sonrası süreç standart TDP cerrahisi ile aynıdır.

Tibial tüberkül osteotomisi ile kuadrisepsplasti yöntemi karşılaştırıldığında, kuadrisepsplastinin daha geniş hareket açıklığı sağladığı ve daha yüksek hasta memnuniyetine sahip olduğu bildirilmiştir. ${ }^{[16]}$ Tibial tüberkül osteotomisinin kas gücünü korumasına rağmen, diz çökme güçlügüü ve ağrı mevcudiyeti nedeniyle ameliyat sonrası klinik fonksiyonel skorlamalarda düşüklüğe neden olduğu da bildirilmektedir. ${ }^{[19]}$

\section{YUMUŞAK DOKULARA YÖNELIK GIRIŞiMLER VE GEVŞETME}

Yukarıda tarif edilen cerrahi kesi ve artrotomi yaklaşımlarından herhangi biri kullanılarak eklem açıldıktan sonra osteotomi işleminden önce yumuşak doku gevşetmeleri ve gerekli doku eksizyonları gerçekleştirilir. 


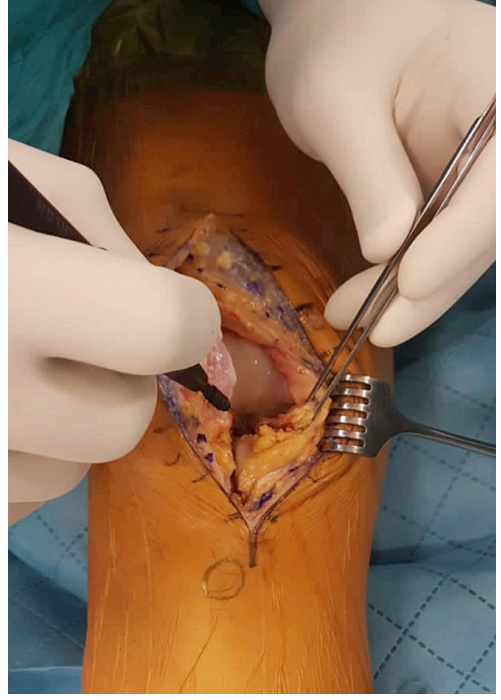

Şekil 9. Artrotomi sonrası tibianın anteromedialinden posteromedialine doğru yapılan gevşetme işlemi.
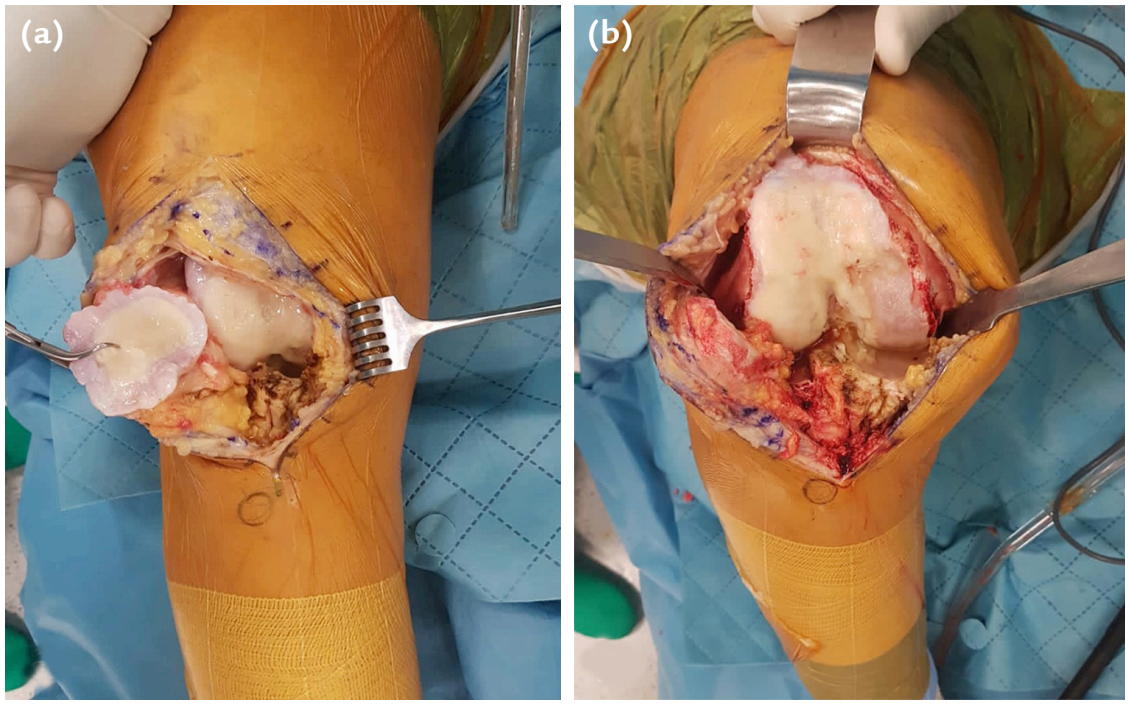

Şekil 10. a, b. Ekstansiyon pozisyonunda patellanın dışa çevrilmesi (a) ve ardından diz fleksiyonu (b).

\section{Yumuşak doku gevşetmeleri}

Ekleme ulaşıldıktan sonra dizin medial tarafı tibianın önünden dizin posteromedial köşesine kadar subperiosteal olarak derin medial kollateral ligamentin ve kapsülün kaldırılmasıyla gevşetilir (Şekil 9). Bu sıyırma varus deformitesi olan dizlerde, valgus deformitesi ve medial kollateral bağ yetersizliği olan dizlere oranla daha da geniştir. Eğer bir dizde varus deformitesi varsa tibial taraftan, valgus deformitesi varsa da femoral taraftan yapılan yumuşak doku gevşetmeleriyle medio-lateral denge oluşturulmaya çalışılır. ${ }^{[20,21]}$ Valgus dizlerde femoral taraftan yapılan yumuşak doku gevşetmesinin nedeni fibuler sinir hasarlanma riskini azaltmaktır. ${ }^{[22]}$ Bağlara longitudinal şekilde gevşetme uygulanmalı, transvers kesilerden kaçınımalıdır. Çoğu varus deformitesinde, derin medial kollateral ligamentin bir kısmı veya tamamı gevşetilir. Bu sayede tibianın dış rotasyonu ve anterior translasyonu kolaylaştırılmış olur. ${ }^{[20]}$ Deneme implantların konulması sonrası medio-lateral dengeye tekrar bakılır ve gerekirse medial kollateral ligamentin yüzeyel kısmı da gevşetilir.

Varus dizlerde, özellikle deneme komponentlerinin yerleştirilmesinden sonra, medial kollateral ligament gerginliğine bağlı sıkılık gözlenen dizlerde gevşetme hamlesi olarak çoklu delme yöntemi kullanılabilir. Bu yöntemde medial kollateral ligamentin derin liflerine farklı yükseklik ve farklı derinliklerde enjektör ucu yardımıyla 8-10 adeti geçmeyecek şekilde delme uygulanır. Bu sayede medial sıkılık gevşetilmiş olur. ${ }^{[23]}$
Gevşetme işlemi sonrasında diz eklemi ekstansiyona alınır. Lateral patellofemoral plika ve varsa daha önceki cerrahilere bağlı yapışıklıklar gevşetilir. Ardından patella dışa çevrilerek diz tekrar fleksiyona alınır ve protez komponentlerinin yerleştirilmesine imkân sağlaması amacıyla diğer yumuşak dokulara ait temizleme işlemlerine geçilir (Şekil 10).

\section{Yă̆ yastıkçığının çıkartılması}

Yağ yastıkçığı dolaşım desteğini superior geniküler arterden alır. Kan akımını korumak için çıkartılması gereken yağ yastıkçı̆̆ı miktarı tartışmalıdır. Miktar az olursa cerrahi görüş engellenebilir, sıkışma ve skar oluşumuna neden olabilir. Bu nedenle sıkışma sorunu olmaksızın iyi bir cerrahi açılım sağlayabilmek için yeterli miktarda yağ yastıkçığı çıkarımı kaçınılmazdır. Bunun yanı sıra lateral açılımda yağ yastıkçığı çıkarımı patellar canlılığı ve lateral yapıları korumak için daha kısıtlı miktarlarda uygulanmalıdır. ${ }^{[24]}$

\section{Ön ve arka çapraz bă̆ temizliği}

TDP cerrahisinde ön çapraz bağ temizliği standart bir uygulamadır ve arka çapraz bağa dokunulmadığı durumlarda arka çapraz bağı koruyan implant sistemleri tercih edilir (Şekil 11). Eğer arka çapraz bağ çok sıkı ise deneme implantlarının ardından gevşetme uygulanabilir. Arka çapraz bağ yetmezliği veya aşırı dejenerasyonu olan durumlarda arka çapraz bağı kesen sistemler kullanılır. ${ }^{[25]}$ Arka çapraz bağ genellikle tibial osteotomi sırasında veya femoral çentik kesisinden önce temizlense de herhangi bir aşamada kesilebilir. Hareketli taşıyıcı (mobile-bearing) bir implant sistemi 

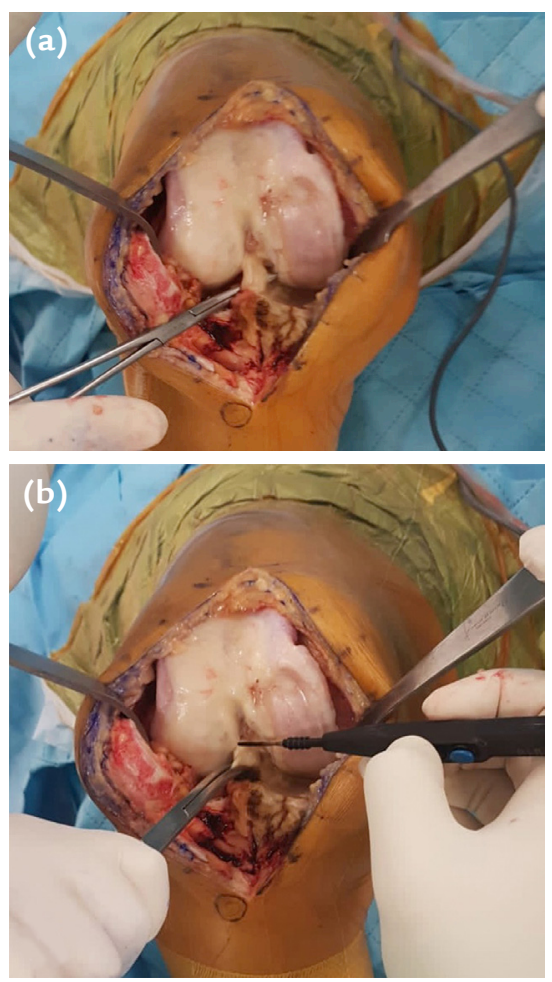

Şekil 11. a, b. Ön çapraz bağ (a) ve eksizyonu (b).

kullanılacaksa fleksiyon ve ekstansiyon aralığı dengesini daha iyi ayarlamak için arka çapraz bağ tibial osteotomi sonrası ve femoral osteotomi öncesi temizlenmelidir. ${ }^{[25]}$ Arka çapraz bağ kesisi sırasında orta geniküler arter zarar görebileceğinden, kanama odağı vakit kaybedilmeden koagüle edilmelidir.

\section{Menisektomi}

Medial ve lateral menisküslerin ön boynuzları ve osteofitler diz fleksiyonu ile kolaylıkla temizlenebilir. Menisküslerin arka boynuzları ise kemik kesilerinden sonra temizlenebilir (Şekil 12). Medial menisküs, derin medial kollateral ligamente o kadar sıkı bir şekilde tutunmuştur ki, ikisi arasındaki sınır çıplak gözle net olarak ayırt edilemeyebilir. Medial menisküsün aşırı rezeksiyonu derin medial kollateral ligamenti, lateral menisküsün aşırı rezeksiyonu ise lateral inferior geniküler arteri hasarlayabilir. Menisküslerin az rezeksiyonu ise cerrahi performansı azaltıp sıkışma sorununa neden olabilir. Eğer eklem mesafesi lateral menisektomi için çok dar ise, öncelikle medial gevşetme yapılmalıdır; sonrasında lateral menisektomi kolaylaşacaktır.

\section{Posterior yapıların temizlenmesi}

Posterior eklem aralığında yer alan yumuşak dokular ve osteofitler, eklem hareketlerinde sıkışmaya ve
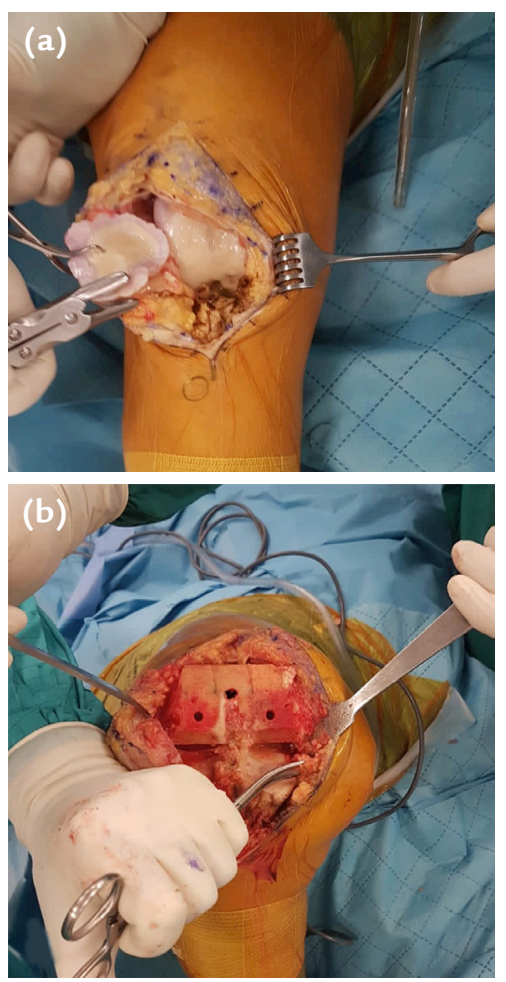

Şekil 12. a, b. Patellar osteofit (a) ve kemik kesisi sonrası menisküsün arka boynuzunun eksizyonu (b).

buna bağlı olarak ağrıya neden olabilmektedir. Daha iyi bir eklem hareket açıklığı elde edebilmek için bu yapılar temizlenmelidir. Sıkışmaya neden olan bu yapıları temizlemek, osteotomiler sonrası daha kolaydır. Posterior eklem aralığında bir miktar fibrotik ve sinoviyal doku ile menisküs yapısının kalmasında sakınca yoktur.

\section{KEMIK KESILERi}

TDP cerrahisinde kemik kesileri ve osteotomilere standardizasyon getirmek amacıyla Hungerford Evrensel Total Diz Enstrümantasyon Sistemi geliştirilmiştir. ${ }^{[22]} \mathrm{Bu}$ kesiler hemen hemen tüm ortopedik cerrahlarca kabul görmüştür. Yapılacak olan temel kesiler protezin tipinden ve tespit şeklinden bağımsız olarak aynıdır. Tek fark arka çapraz bağın korunmadığı tiplerde interkondiler bölgenin çıkarılması basamağıdır. Ameliyat sonrası ideal dizilimin sağlanması için doğru kemik kesilerinin yapılması şarttır. Doğru kemik kesileri ve dengeli yumuşak doku gevşetmeleri ile yer düzlemine paralel ve fleksiyon-ekstansiyon aralığı eşit olan bir eklem aralığı elde edilmelidir. ${ }^{[1,7,22,26]}$ Aksi takdirde, uygun olmayan kesilere bağlı olarak gelişen dizilim bozukluğu, komponentlerde eşit olmayan yüklenmelerle instabilite ve gevşemeye yol açar. 

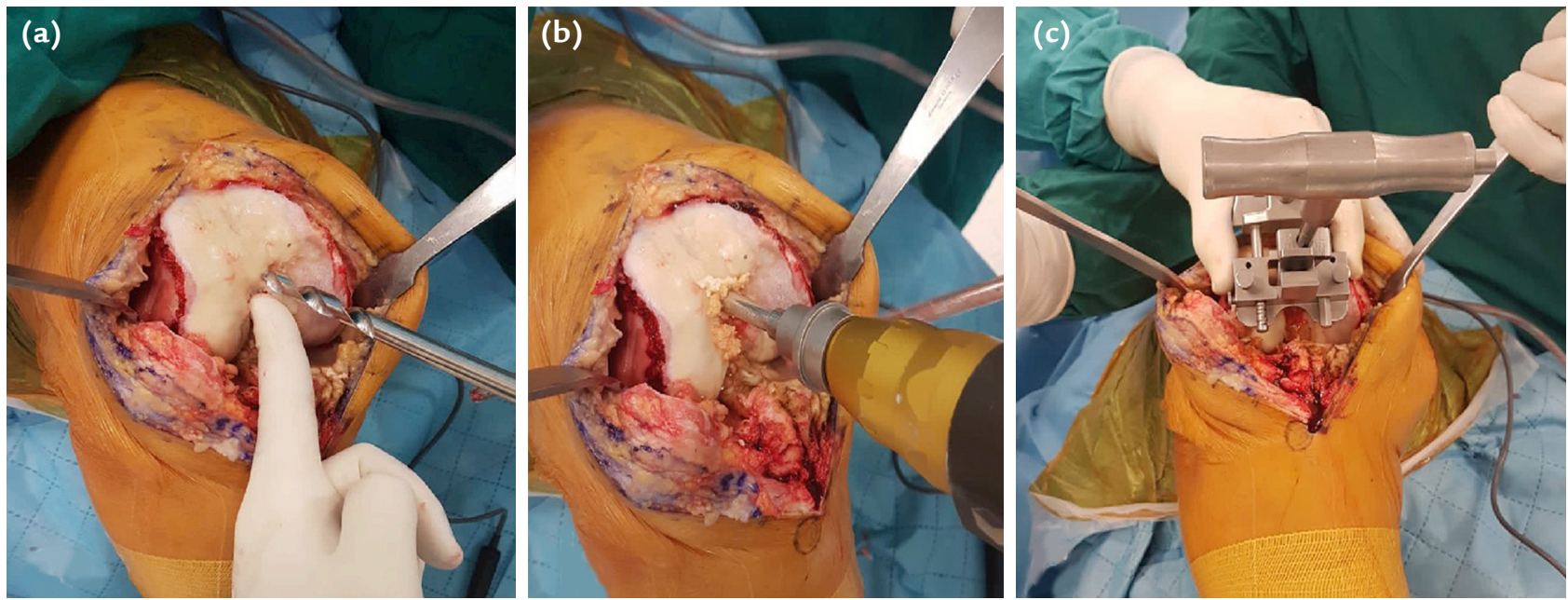

Şekil 13. a-c. İntramedüller femoral kılavuzun giriş yerinin belirlenmesi (a), kanalı ortalayacak şekilde delik açılması (b) ve kılavuzun yerleştirilmesi (c).
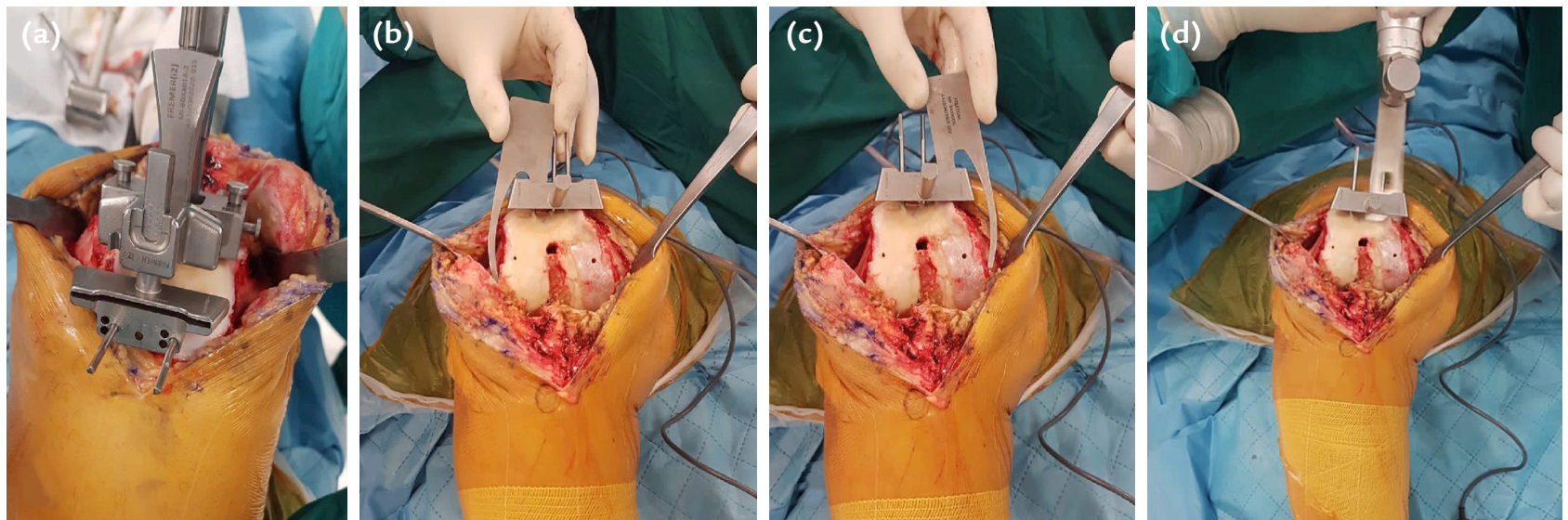

Şekil 14. a-d. Distal femoral kesi öncesi kesi bloğunun yerleşimi (a), femur kesisinin lateral (b) ve medial (c) taraftan kontrolü ardından distal femur kesisi (d).

TDP cerrahisinde dört ana, iki adet de isteğe bağlı kesi gerçekleştirilir. Bunlar;

1. Distal femur kesisi

2. Anterior ve posterior kondil kesileri

3. Anterior ve posterior köşe (chamfer) kesileri

4. Proksimal tibia kesisi

5. İnterkondiler çentik (notch) kesisi (arka çapraz bağ kesen tip protezler için)

6. Patellar kesi (patellar komponent uygulanacaksa)

\section{Distal femur kesisi}

Distal femur kesisinde sıklıkla intramedüller kılavuz kullanılmaktadır. İntramedüller kılavuzun giriş deliği orta hatta interkondiler çentiğin merkezinin 3-4 mm medialinde, arka çapraz bağın medial femur kondiline yapışma yerinin $1 \mathrm{~cm}$ anteriorunda olmalıdır (Şekil 13). Intramedüller kılavuz, kanalın merkezinden gönderilmelidir. Eğer kılavuz medulla içerisinde lateral kortekse dayanacak olursa, tasarlanmış valgus açısı azalacaktır. Medial kortekse dayanması durumunda ise valgus açısı artar. Ameliyat öncesi grafilerde femoral kanalda darlık veya deformite, kötü kaynama ve daha önce yapılmış aynı taraf kalça protezi varlığı değerlendirilmelidir; bunların herhangi birinin mevcudiyetinde ekstramedüller kılavuz kullanılmalıdır. ${ }^{[1,7,22,26]}$

İntramedüller kılavuz yerleştirildikten sonra, bu kılavuza $5^{\circ}-7^{\circ}$ valgus açısında, mekanik aksa dik kesim yapılmalıdır. Bu kesi hattı hiçbir zaman yan bağların yapışma yerinin daha üstünde olmamalıdır (Şekil 14). Proksimal tibial kesi de, tibianın mekanik aksına dik yapılacağından, fleksiyonda dikdörtgen bir eklem 

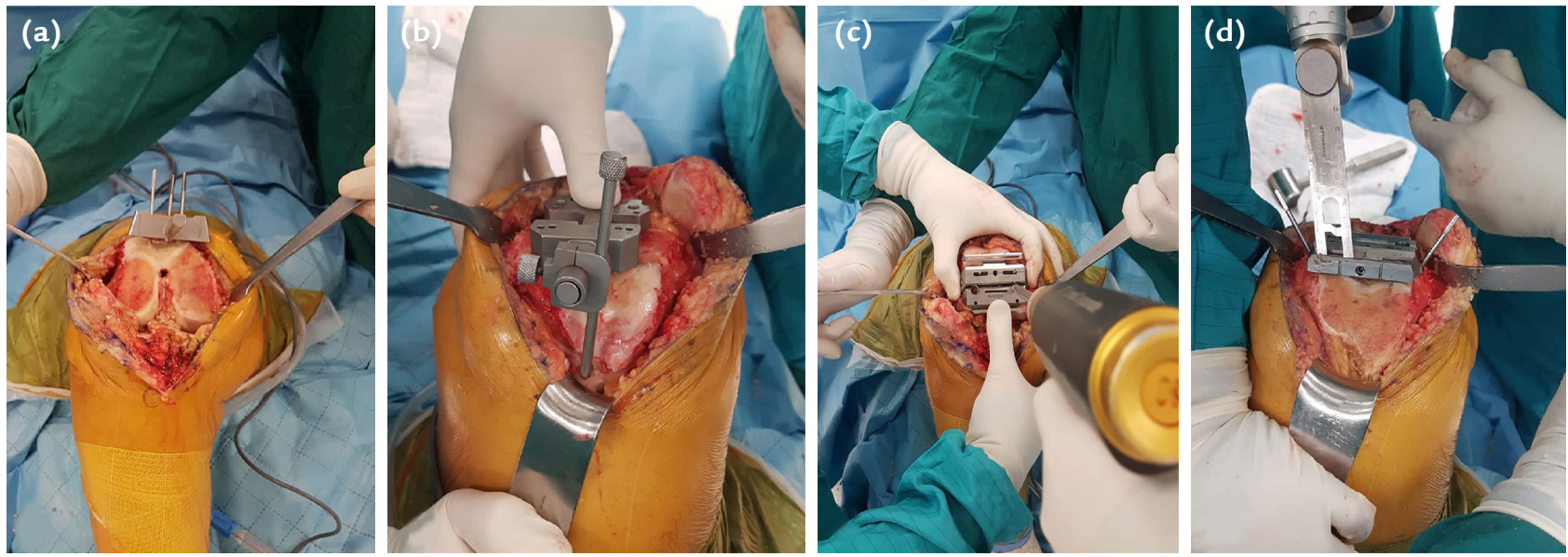

Şekil 15. a-d. Distal femoral kesi sonrası (a), kesi kılavuzunun distal kesi yüzeyine arada boşluk kalmayacak şekilde yaslanması (b), kesi bloğunun sabitlenmesi (c) ve anterior kondil kesisi (d).

aralığı elde edebilmek için, distal femoral kesinin $3^{\circ}$ dış rotasyonda yapılması gerekmektedir.

\section{Anterior ve posterior kondil kesileri}

Distal femur kesisi sonrasında, antero-posterior femoral mesafe ölçülerek, uygun femoral komponent boyutu hesaplanır. ${ }^{[1,7,22,26,27]}$ Femoral komponentin ölçü hesabında temel amaç, mümkün olan en küçük boyutlu protezi anterior femoral çentiklenmeye sebep olmadan yerleştirmektir. En sık tercih edilen yöntem posterior referans tekniğidir. Distal femoral kesiyi takiben, kesi kılavuzu posterior kondillere yerleştirilerek distal kesi yüzeyine arada boşluk kalmayacak şekilde yaslanır ve stilus anterior korteksin en yüksek noktasına temas ettirilir (Şekil 15). ${ }^{[7,27]}$ Posterior kondilden yapılacak kesi miktarı sabittir ve komponent boyutuyla değişmez. Böylelikle fleksiyon ve ekstansiyon aralıklarında eşitsizlik yaratıcı bir durumun oluşması beklenmez. Büyük boy protez kullanılması eklemde fleksiyon kısıtlılığına yol açacaktır. Buna karşın ölçülen boyut arada ise kullanılacak alt boy kesi aparatı anterior femoral korteksten daha fazla kesi yapılmasına neden olacak ve anterior femoral çentiklenmeye yol açacaktır. Ancak uygun boyutta femoral komponentin yerleştirilmesi her halükarda eklemde daralmaya neden olabilir. ${ }^{[7-27]}$

Anterior referans tekniğinde, femoral komponent boyut ölçümü anterior femoral korteks seviyesine göre yapılır. Ölçüm kılavuzu transepikondiler hatta paralel olacak şekilde yerleştirilmelidir. Bu teknikte uygulanan anterior femoral korteks kesisi sabit olduğundan, patellofemoral eklem üzerine olumsuz etki yaratması ve anterior femoral çentiklenmeye sebep olması da beklenmez. Ancak posterior femoral kondilden yapılan kesi değişiklik gösterebileceğinden, bu durum fleksiyon aralığının geniş kalmasına ve fleksiyonda instabiliteye neden olabilir. ${ }^{[7,27]}$

Anterior kesi ile posterior kondiler kesiler, femoral komponentin rotasyonunu ve fleksiyon aralığını belirler. Fazla dış rotasyon, fleksiyon aralığının medialden açılmasına neden olur ve fleksiyon instabilitesine yol açar. Femoral komponentin iç rotasyonunda artış ise lateral patellar tilte, hatta patellofemoral instabiliteye neden olur. Birkaç farklı yöntemle femoral komponentin rotasyonu belirlenebilir. Referans noktaları olarak transepikondiler aks, anterior-posterior aks (whiteside çizgisi) veya posterior femoral kondiler aks kullanılabilir (Şekil 16). Eğer transepikondiler aks kullanılacaksa, posterior femoral kesi, medial ve lateral femoral epikondillerin arasındaki izafi çizgiye paralel yapılmalıdır.

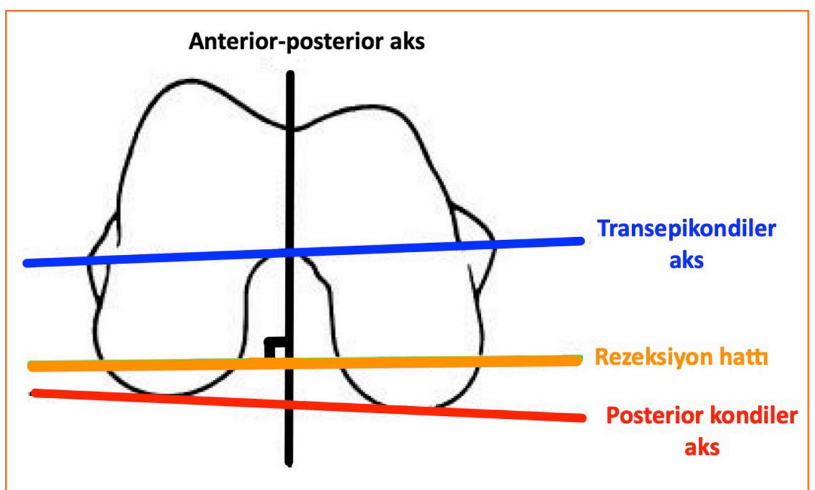

Şekil 16. Normal kondiler şekli olan bir dizde posterior kondil kesisi için femoral komponent rotasyonunun ayarlanmasında kullanılabilecek dizilim aksları. 

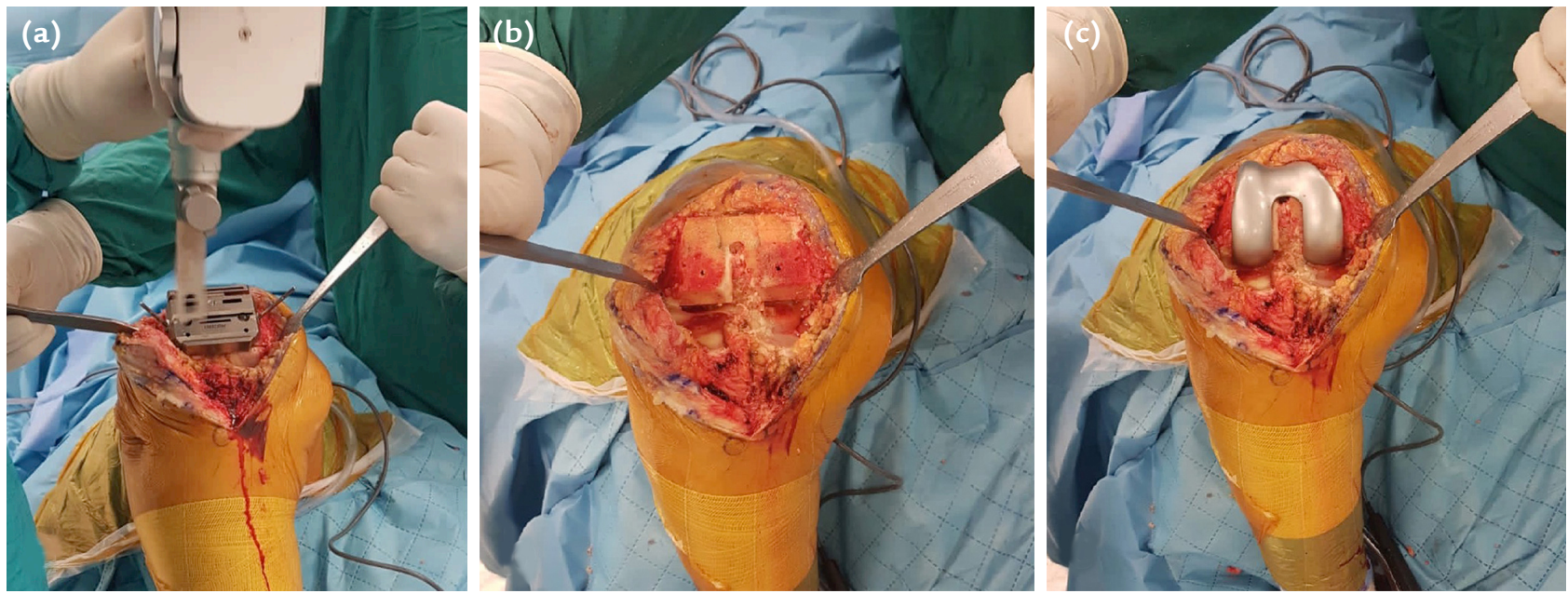

Şekil 17. a-c. Kesi bloğu üzerinden köşe (chamfer) kesileri (a), arka çapraz bağı koruyan bir diz protezi cerrahisinde distal femoral hazırlığın bitmiş hali (b) ve femoral deneme komponentinin görüntüsü (c).

Anterior-posterior aks kullanılacaksa, posterior kondiler kesi bu eksene dik olarak gerçekleştirilmelidir. Posterior kondiler aks referans alınacaksa, kondiller arasındaki çizgiye $3^{\circ}$ dış rotasyon verilerek kesim yapılmalıdır. ${ }^{[1,22]}$

\section{Anterior ve posterior köșe (chamfer) kesileri}

Anterior ve posterior köşe kesileri yapılarak femoral komponent ile distal femurun tam olarak teması sağlanır. Bu kesilerle birlikte arka çapraz bağı koruyan protez için gereken distal femoral hazırlık sonlanmış olur (Şekil 17).

\section{Proksimal tibial kesi}

Eklem seviyesinin orjinal yüksekliğinin korunması, tibial platoda yapılacak keside dikkat edilecek en önemli noktadır. Eklem seviyesi anatomik olarak medial femoral epikondilin $3 \mathrm{~cm}$ kadar distalinde, fibula başının ise $1,5 \mathrm{~cm}$ kadar proksimalinde bulunmaktadır. ${ }^{[7,22]}$ Proksimal tibia kesisi, tibia mekanik ve anatomik aksına dik açıda olmalıdır. Bu amaçla ekstramedüller veya intramedüller tibial kesi kılavuzları kullanılabilir. Standart bir proksimal tibia kesisinde, posteriora $4^{\circ}-7^{\circ}$ eğim verilmelidir. Proksimal tibia kesisinin ideal amacı, az kemik kesisi ile subkondral kemiğe ulaşmak, tibial komponenti buraya yerleştirmek ve mümkün olan en ince boyutta polietilen insert kullanmaktır. ${ }^{[1,7,22]}$

Ekstramedüller kılavuz kullanıldığında, kılavuz aparatının distali medial ve lateral malleolün hemen üzerine yerleştirilip uygun dizilim sağlanmalıdır. Tibial kesi bloğunun üzerinde hareket ettiği çubuk (rod), ayak 2 . metatarsı referans alınarak yerleştirilmelidir. Böylece

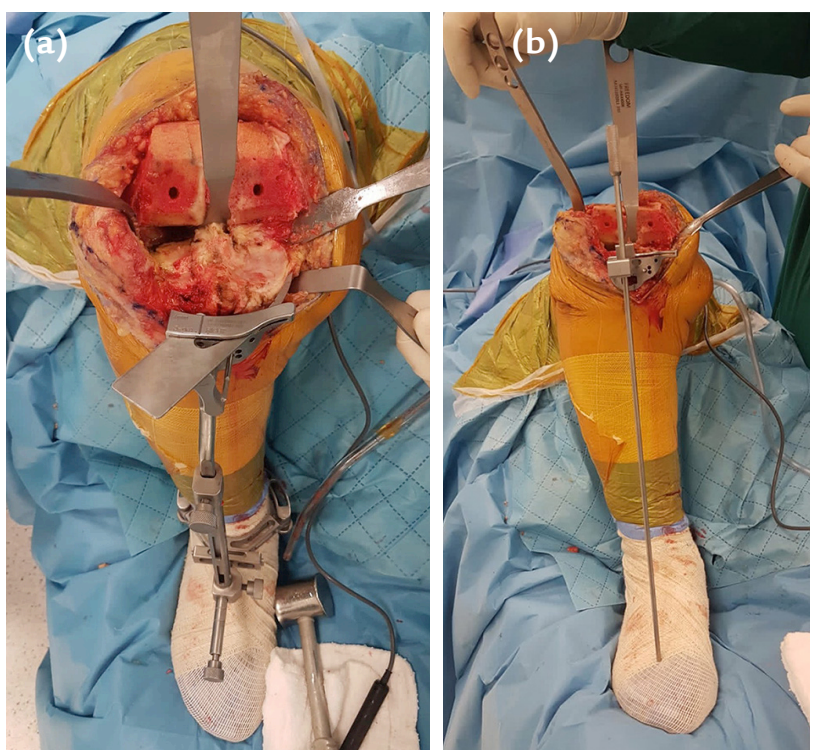

Şekil 18. a, b. Ekstramedüller kılavuzun yerleşimi (a) ve kılavuz rodu ile uygun dizilimin kontrolü (b).

ekstramedüller kılavuz rodun, talar kubbeyi (domu) merkezleyerek yerleştirilmesi sağlanmış olur (Şekil 18 ). Normalde talar domun merkezi, medial ve lateral malleollerin dış kenarlarını birleştiren hattın orta noktasının yaklaşık $5 \mathrm{~mm}$ medialinde yer almaktadır. $\mathrm{Bu}$ aşamada, ekstramedüller rod, talar dom merkezi yerine ayak bileği merkezinden geçerse, tibial komponentin varus pozisyonunda yerleştirilmesine sebep olur. Aynı zamanda ekstramedüller kılavuz kullanımında rod, tibia anterior kenarına parallel seyretmelidir. Paralelliğin bozulduğu durumlarda tibial kesinin antero-posterior dengesi ve dolayısıyla posterior tibial eğim açısı değişecektir. 

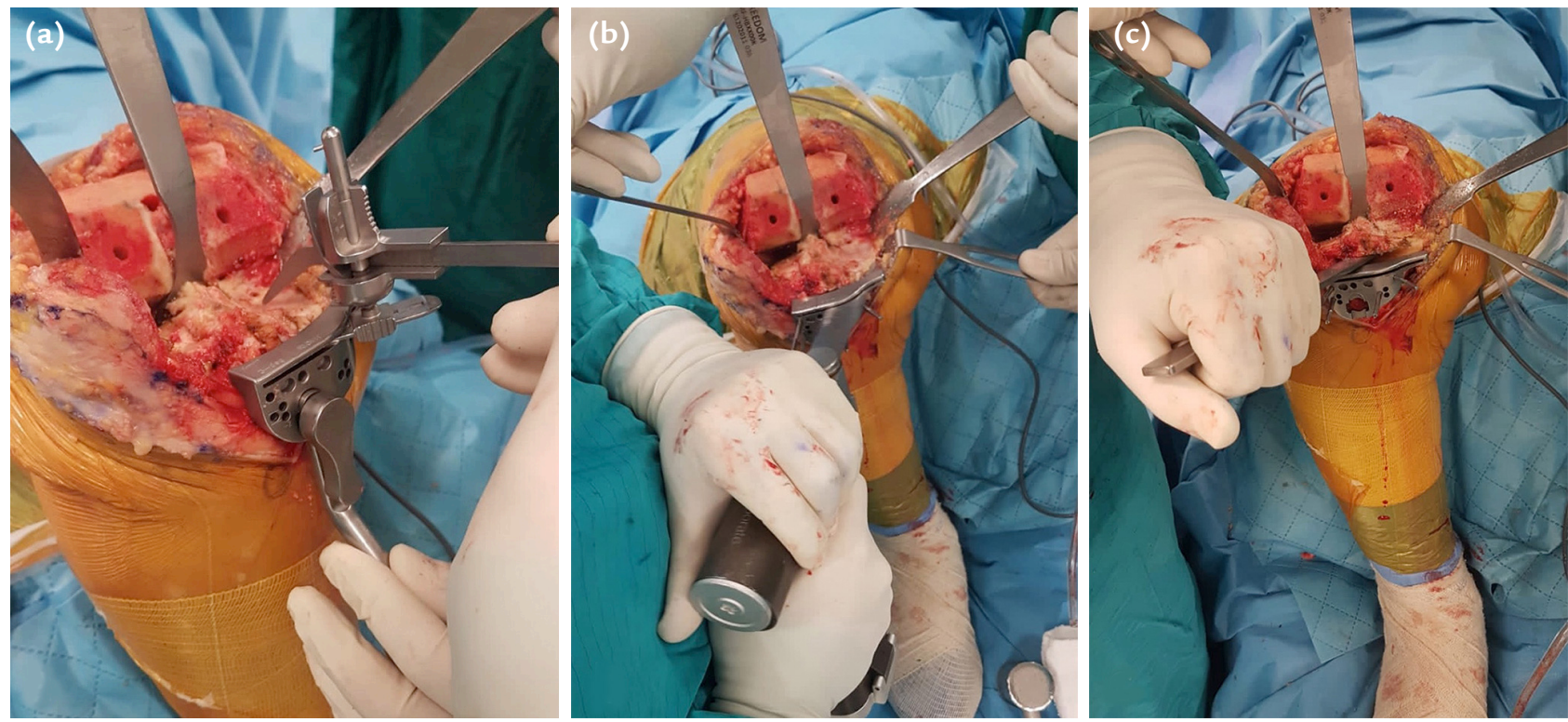

Şekil 19. a-c. Stilus yardımıyla kesi seviyesinin belirlenmesi (a), proksimal tibial kesi (b) ve tibia platosunun elevasyonu (c).

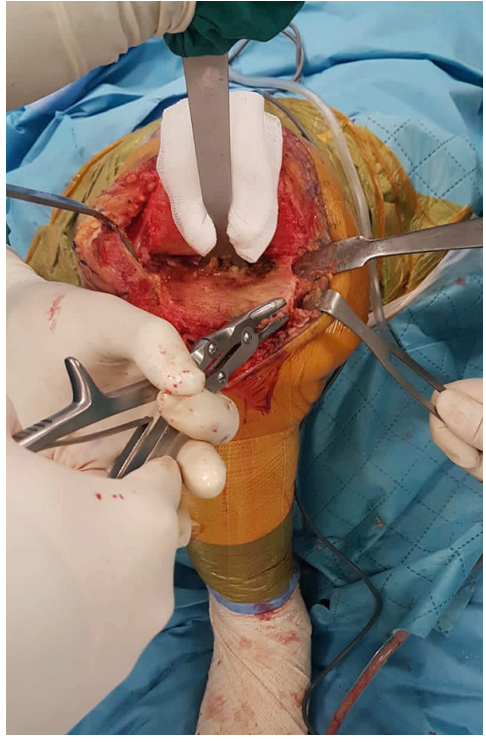

Şekil 20. Tibial osteofitlerin temizlenmesi.

İntramedüller kılavuz kullanımında ise rod giriş yeri anterior-posterior planda ön çapraz bağın yapışma yeri, medio-lateral planda ise tam orta hattadır. Eğer giriş daha posteriordan yapılırsa posterior tibial eğim açısı artacaktır. İntramedüller kılavuz kullanımında tibia anatomik hattına paralellik mutlaka kontrol edilmelidir.

Tibial kesi seviyesini belirlemek amaciyla proksimal tibia kesim kılavuzu yerleştirilir ve stilus kullanılır (Şekil 19). Amacı minimum kemik kesisi yapmak olan stilusun iki ayar seçeneği mevcuttur. Birincisi $2 \mathrm{~mm}$ uzunluğunda olup defektli tibia kondilinde minimal kesim yapılmasını sağlar. İkincisi ise $9 \mathrm{~mm}$ uzunluğunda olup daha iyi durumda olan tibial kondile yerleştirilerek uygun kesinin yapılmasını sağlar. Varus dizilimi olan artritik dizlerle daha sık karşılaşıldığı için 2 mm'lik stilus defektli medial tibial kondile yerleştirilir ve minimum kemik kesisi yapılmaya çalışılır. Kesi seviyesi kılavuz yardımıyla belirlendikten sonra arka çarpraz bağ korunacak ise önce ince bir osteotom ile arka çarpraz bağın yapışma sınırları işaretlenir. Yaklaşık $1 \times 1 \mathrm{~cm}$ ebatlı kemik blok kalması yeterlidir.

Proksimal tibia kesisini takiben tibial komponent boyutunun ölçümüne geçilir. Özellikle medial tibial platodaki osteofitler ölçüm esnasında yanıltıcı olabilir. Bu yüzden proksimal tibial kesiyi yaptıktan sonra bu bölgedeki osteofitlerin temizlenmesi gerekir (Şekil 20). Osteofitlerin alınması aynı zamanda medial kollateral bağdaki gerginliği de azaltacaktır. Ölçümü takiben deneme tibial komponent, yüzeye pinler yardımıyla uygun rotasyonda yerleştirilir. ${ }^{[1,7,22,27]}$ Tibial komponentin rotasyonu da en az femoral komponentin rotasyonu kadar önemlidir. Komponentlerin rotasyon kusurları patellofemoral eklemde aşırı yüklenmeye, subluksasyona hatta patellofemoral dislokasyonlara neden olabilir. Ekstramedüller kılavuz aparatının 2. metatarsa uzanımının değerlendirilmesi, rotasyon tespitinde tek başına güvenli bir yöntem değildir. Tibial komponentin rotasyon değerlendirmesinde tüberositas tibia, 2. metatars ve tibia platosu transvers ekseni birlikte kullanılan referans noktalarıdır. Tibial komponentin orta noktası tüberositas tibianın 


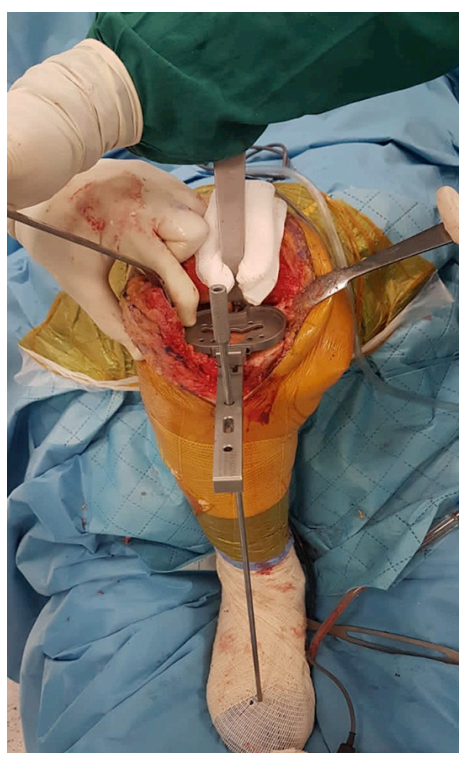

Şekil 21. Proksimal tibial kesi sonrası tibial komponent rotasyonunun ve aksının kontrolü.
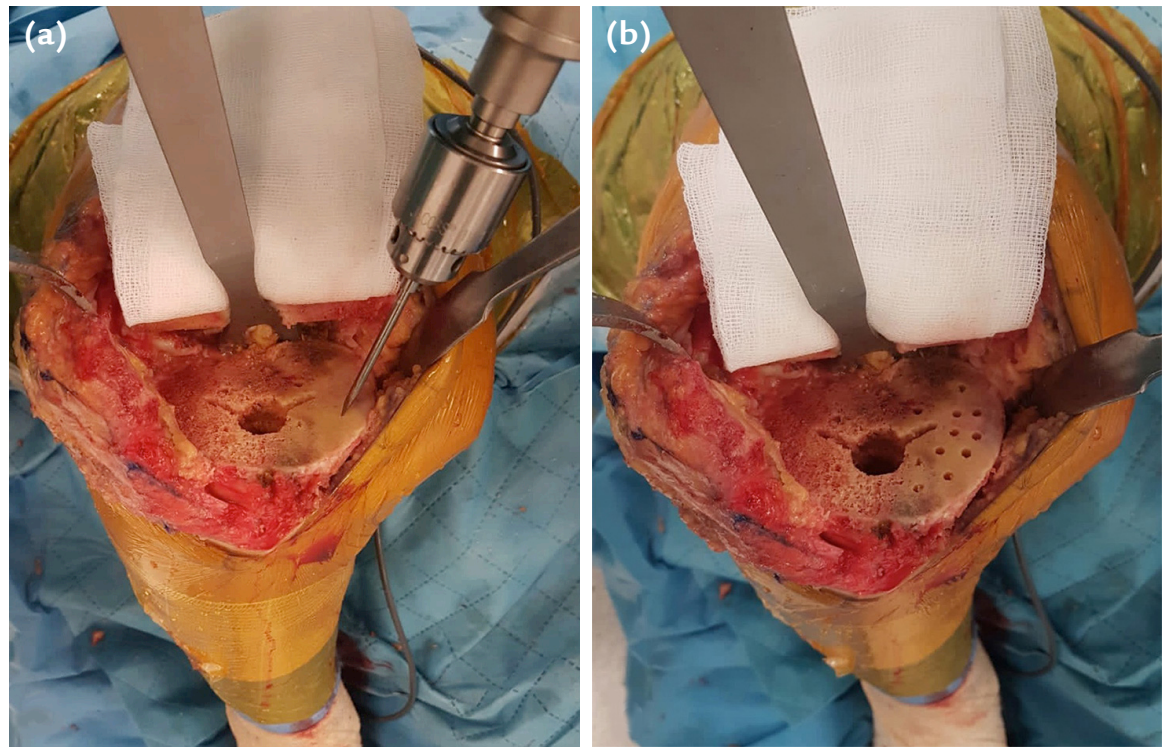

Şekil 22. a, b. Medial tibia platosundaki sklerotik alan (a) ve çimento temas yüzeyini artırmak amacıyla çoklu delik açma (b). medialinde kalmalıdır (Şekil 21). Tibial plato transvers aksı ile tibial komponent transvers aksı birbirlerine paralel olmalıdır. Tibial komponentin yerleştirilmesinde her zaman medial ve posterior taşmadan kaçınılmalı ve komponentin medial kollateral bağ üzerinde yaratacağı gerginlik önlenmelidir.

Kemik defektleri tibial kesilerde karşılaşılan bir diğer sorundur. Bu defektlerin çesitli sebepleri olabilir. Bunlardan bazıları; artroza bağlı açısal deformite, kondiler hipoplazi, travma, avasküler nekroz ve daha önce yapılmış yüksek tibial osteotomi ve total diz protezi ameliyatlarıdır. Kemik defektlerine tibial tarafta, femur kondillerine nazaran daha sık rastlanmaktadır. Defektler santral, periferik veya her ikisinin kombinasyonu şeklinde karşımıza çıkabilir. Kaviter defektlerde kusurlu bölgeyi çevreleyen kortikal kemiğin sınırı bozulmamıştır. Aksine segmental eksikliklerde kemiğin kortikal bir sınırı yoktur ve bu defektler daha periferiktir. Bu tarz bölgelerde komponent özellikle desteklenmelidir. Defekt artışını önlemek amacıyla fazla kesiden kaçınılmalı, bu tarz bölgeler defektin boyutuna göre çimento, kemik grefti veya kama kemik parçaları ile desteklenmelidir. Tibia platosunun 1/3'ünden az kısmını kapsayan $5 \mathrm{~mm}$ altındaki defektler çimento ile desteklenebilir. Genellikle bu tarz defekt bölgeleri aşırı sklerotik olup, komponente iyi destek sağlayacak yapıya sahiptir. Bu yüzeylere çoklu delik açma işlemi ile kemik çimento temas yüzeyi artırılarak tespit güçlendirilir (Şekil 22). Genelde yüzeyin 1/3'ünden fazla olan 5-10 mm'lik defektlerin giderilmesinde ise kemik grefti kullanılabilir. Kemik kesileri esnasında osteomize edilen femoral kondil parçaları, tibial defektin giderilmesinde kullanılabilir. Daha geniş yüzey içeren $10 \mathrm{~mm}$ ve üzeri defektler ile femoral kondil defektleri kama destekleri ile giderilebilir. ${ }^{[1]}$

\section{Notch kesisi}

Eğer arka çapraz bağı kesen bir protez çeşidi seçilmişse bağın fonksiyonunu karşılayan "posterior cam" mekanizması için bu kesinin yapılması gereklidir. ${ }^{[1,7]}$

\section{Patellar kesi}

Patella ortalama $25 \mathrm{~mm}$ kalınlığındadır. Eğer patella kesisi yapılacaksa osteotomi sonrası en az $15 \mathrm{~mm}$ kalınlılığı koruyor olması gerekir. Bu kalınlığın altında patellar kesi yapılması kırık riskini artıracaktır. Patellar faset asimetrisinden dolayı, lateralde aşınma miktarı daha fazladır. Dolayısıyla iç taraftan daha fazla kemik alınması gerekir. Uygulanan osteotomi, patellanın ön yüzüne paralel olmalı ve aynı zamanda lateralde subkondral kemiğe kadar inmelidir. Özellikle arka çapraz bağın korunduğu protezlerde patellar osteotomi az yapılacak olursa, patellar komponent uygulaması sonrası patellar kalınlık artmış olur. Bu durumda ekstansör mekanizma gerilecek ve fleksiyon kısıtlılığı ortaya çıkacaktır. Uygulamadaki hatalardan kaynaklanabilen bir diğer durum ise, patellar instabilitedir. Ameliyat öncesinde patellanın sublukse olmadan femoral olukta rahatça hareket edip etmediği kontrol edilmelidir. Bu esnada çamaşır klempi veya geçici dikiş koyulmamalı, 

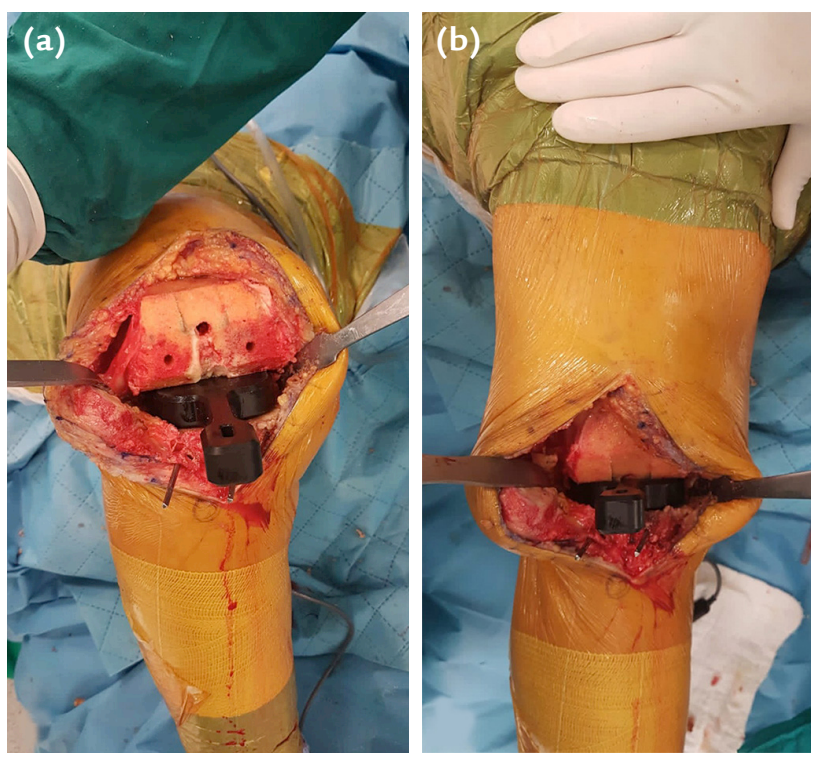

Şekil 23. a, b. Kemik kesileri sonrası fleksiyon (a) ve ekstansiyon (b) aralıklarının kontrolü.

başparmak yardımı olmadan diz fleksiyon-ekstansiyonu sırasında subluksasyon kontrol edilmelidir. Aksi takdirde lateralden gevşetme uygulanmalıdır. $[1,7,22,27]$

\section{FLEKSIYON VE EKSTANSIYON ARALIKLARININ DENGELENMESI}

Kemik kesileri sonrasında fleksiyon ve ekstansiyon aralıklarının değerlendirilmesi oldukça önemlidir. Tibial kesi yüzeyi ile posterior femoral kondiler kesi yüzeyi fleksiyon aralığını oluştururken, tibial kesi yüzeyi ile distal femoral kesi yüzeyi ekstansiyon aralığını oluşturur. Kemik kesileri sonrasında fleksiyon ve ekstansiyon araIıkları eşit olmalıdır (Şekil 23). Bu aralıkların yeterince dengelenemediği durumlarda dizde değişen oranlarda hareket kısıtılığı gelişecektir. Ekstansiyon aralığının fleksiyon aralığından daha dar olduğu durumlarda dizde ekstansiyon kısıtlılığı gelişecek ve kalıcı fleksiyon kontraktürü ortaya çıkacaktır. Bu durumun oluşmaması için posteriorda kalan (rezidü) osteofitler temizlenmeli, posterior kapsüle gevşetme uygulanmalı, ihtiyaç halinde de distal femoral yüzeyden ek kesi yapılarak ekstansiyon aralığı genişletilmelidir (Şekil 24). ${ }^{[1,7,27]}$ Fleksiyon aralığının ekstansiyon aralığından daha dar olduğu durumlarda ise dizde fleksiyon kısıtlılığı gelişecektir. Bu durumda ilk olarak posterior tibial eğim açısı $7^{\circ}$ yi geçmeyecek şekilde artırılabilir. İkinci seçenek olarak da femurda bir boy küçük proteze geçilerek fleksiyon aralığı artırılmaya çalışılır. ${ }^{[1,7,27]}$ Fleksiyon ve ekstansiyon aralıklarının her ikisinin de dar olduğu durumlarda, diz ekleminde fleksiyon ve ekstansiyonda kısıtlılık

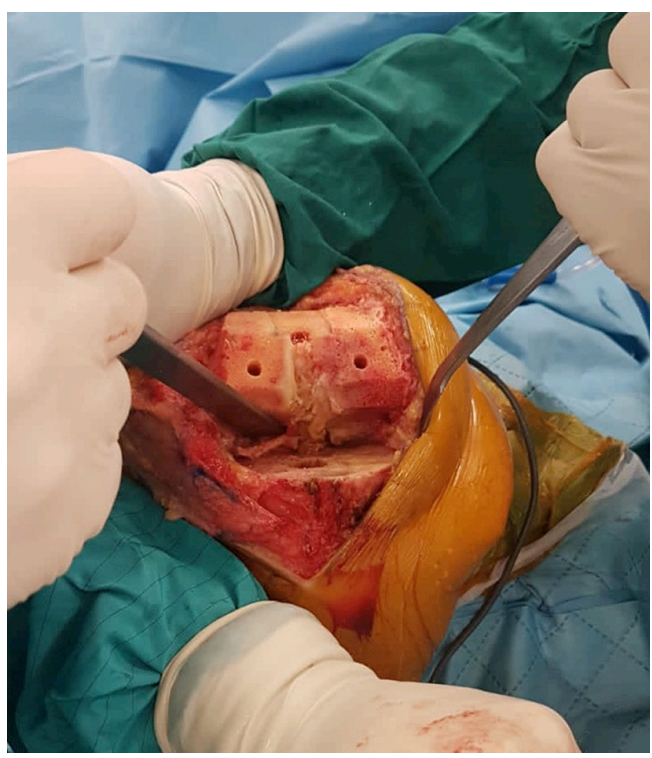

Şekil 24. Femur kondilinin posteriorunda kalmış olan osteofitlerin temizlenmesi.

karşımıza çıkacaktır. Her iki aralığın oluşumuna katkıda bulunduğundan, tibial yüzeyden yapılacak ek kesi bu sorunu çözmeye yardımcı olacaktı..$^{[1,7,27]}$ Fleksiyon ve ekstansiyon aralıkları ile ilgili oluşabilecek sorunlar ve çözümleri Tablo 1'de özetlenmiş̧tir.

\section{KOMPONENTLERIN YERLEŞTIRILMESI VE KAPAMA}

Kemik kesileri tamamlanıp, yumuşak doku dengesi sağlandıktan sonra deneme komponentler ile diz eklem stabilitesi ve dizilimi değerlendirilir (Şekil 25a). Ardından deneme komponentler çıkartılır, spongiyoz kemik görünecek şekilde basınçlı serum fizyolojik ile yıkama-kurulama yapılır ve asıl protezin komponentlerinin hazırlanma ve uygulama sürecine geçilir. Bu aşamada dize hiperekstansiyon yapılmaz. Çünkü eklem içeride protez ve insert olmadan instabildir ve posteriordaki nörovasküler yapılara zarar verilebilir. Femoral kanala ve eğer tibiada intramedüller kılavuz kullanıldıysa tibial kanala, stem seviyelerine kadar daha önceden alınan kemiklerden hazırlanmış tıkaçlar yerleştirilir. Ardından asıl protezler çimentolanarak yerleştirilir. Deneme tibial insert de yerleştirilerek diz tam ekstansiyona alınır ve çimentonun donması beklenir. Donma sonrasında deneme tibial insert gerekli temizliklerin ardından aslıyla değiştirilir (Şekil 25b).

Asıl protezler ve insert yerleştirildikten sonra anestezi ekibine bilgi verilerek turnike açılır. Bu sırada gelişebilecek ani hipotansiyona karşı dikkatli 
Tablo 1. Fleksiyon ve ekstansiyon aralıkları ile ilgili oluşabilecek sorunlar ve çözümleri

\begin{tabular}{lll}
\hline Senaryo & Sorun & Çözüm \\
\hline $\begin{array}{l}\text { Ekstansiyon gergin } \\
\text { Fleksiyon gergin }\end{array}$ & $\begin{array}{l}\text { Simetrik aralık } \\
\text { Tibia az kesilmiş }\end{array}$ & Proksimal tibiadan fazla kesi \\
$\begin{array}{l}\text { Ekstansiyon gevşek } \\
\text { Fleksiyon gevşek }\end{array}$ & Kalın insert kullanılması \\
$\begin{array}{l}\text { Ekstansiyon iyi } \\
\text { Fleksiyon gevşek }\end{array}$ & Tibia fazla kesilmiş & Femoral komponentin bir büyüğüyle değiştirilmesi \\
$\begin{array}{l}\text { Ekstansiyon iyi } \\
\text { Fleksiyon gergin }\end{array}$ & $\begin{array}{l}\text { Asimetrik aralık } \\
\text { Posterior femur kesisi çok }\end{array}$ & \\
Ekstansiyon gevşek & Asimetrik aralık & Femoral komponentin bir küçüğü ile değiştirilmesi \\
Fleksiyon iyi & AÇB gergin & AÇB kesilmesi \\
Ekstansiyon gergin & Asimetrik aralık & \\
Fleksiyon iyi & Distal femur kesisi çok & Distal femurun desteklenmesi \\
& Asimetrik aralık & Kalın insert kullanılması \\
\hline
\end{tabular}

AÇB, arka çapraz bağ.
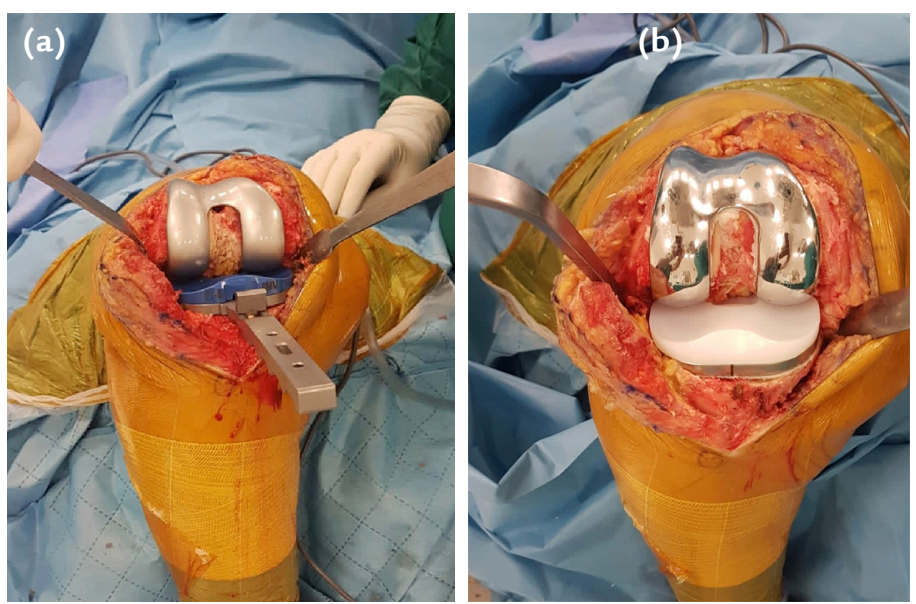

Şekil 25. a, b. Deneme komponentler ile diz eklem stabilitesinin değerlendirilmesi (a) ve kalıcı implantların yerleştirilmesi (b).

olunmalıdır. Yaraya serum fizyolojik emdirilmiş bezlerle basınç uygulanır ve hemostaz sağlanır. Geniküler arterlerden kanama olmadığından emin olunmalıdır. Bu amaçla eklem dört kadrana ayrılıp her kadranda ayrıntılı bir şekilde kanama kontrolü yapılır (Şekil 26a). Ardından patella çevresi osteofitler temizlenip cerrahın tercihine göre koter yardımıyla desensitizasyon uygulanabilir (Şekil 26b). Bunların yanısıra turnike açılmadan ve dren koyulmadan kapama yapılmasını savunan yayınlar da vardır. ${ }^{[1,7,22]}$ Kapama öncesi geçici bir dikiş veya çamaşır klempi yardımıyla fasya birleştirilir ve diz eklemine $90^{\circ}$ 'yi geçecek şekilde fleksiyon ve ekstansiyon yaptırılır (Şekil 27). Patellanın sulkus ile uyumu değerlendirilir. Ardından artrotomi kesisi, erimeyen kalın bir dikişle patellar
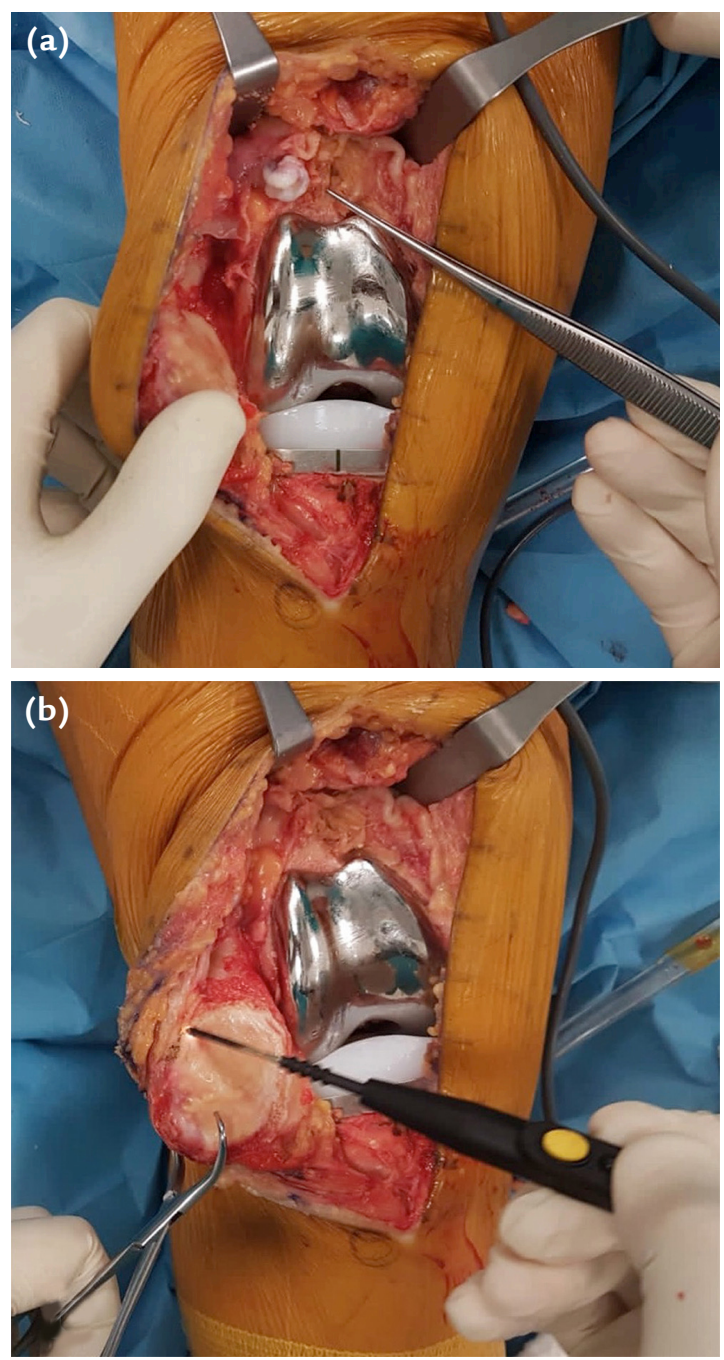

Şekil 26. a, b. Kanama kontrolü (a) ve patellar desensitizasyon (b). 

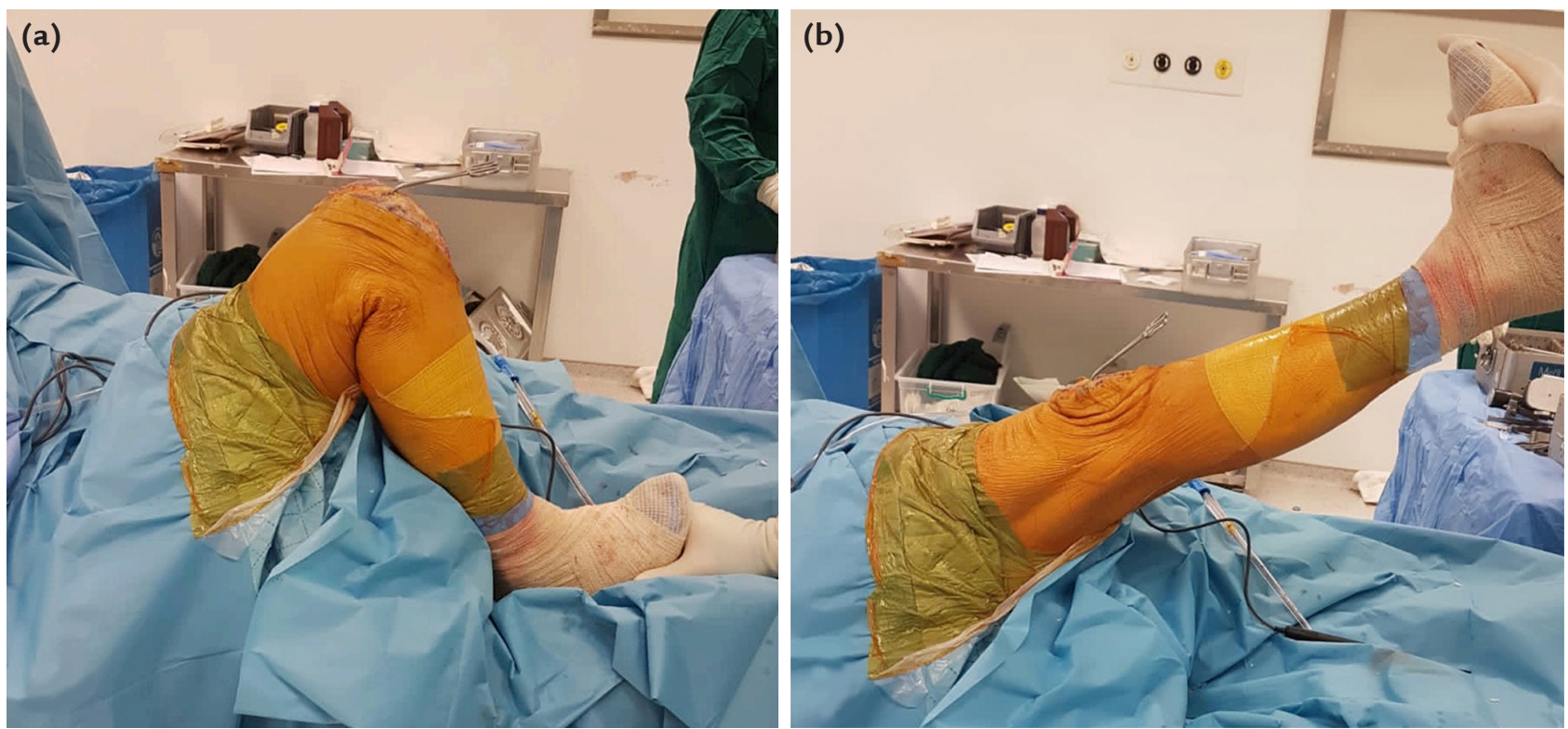

Şekil 27. a, b. Kapama öncesi diz fleksiyon (a) ve ekstansiyonunun (b) kontrolü.

periostu da içine alacak şekilde kapatılır. Dren koyulduysa, tespit edilmeden önce ileri geri hareket ettirilerek kapama esnasında içinden dikiş geçip geçmediği kontrol edilmelidir. Dren, rahat hareket ediyorsa bu aşamada cilde tespit edilebilir. Sonrasında cilt altı ve cilt, diz eklemi $30^{\circ}-40^{\circ}$ fleksiyonda uygun dikiş materyalleri kullanılarak kapatılır. ${ }^{[1,7,22]}$

\section{KAYNAKLAR}

1. Dorr LD, Boiardo RA. Technical considerations in total knee arthroplasty. Clin Orthop Relat Res 1986;(205):5-11. Crossref

2. Gomez S, Yasgur DJ, Scuderi GR, Insall JN. Draping technique for total knee arthroplasty. In: Scuderi GR, Tria AJ, editors. Surgical Techniques in Total Knee Arthroplasty, 1st ed. New York: Springer; 2002. p.168-73. Crossref

3. Wakankar HM, Nicholl JE, Koka R, D’Arcy JC. The tourniquet in total knee arthroplasty. A prospective, randomised study. J Bone Joint Surg Br 1999;81-B(1):30-33. Crossref

4. Barrack RL, Smith P, Munn B, Engh G, Rorabeck C. The Ranawat Award. Comparison of surgical approaches in total knee arthroplasty. Clin Orthop Relat Res 1998;356:16-21. Crossref

5. Haertsch PA. The blood supply to the skin of the leg: a postmortem investigation. Br J Plast Surg 1981;34(4):470-77. Crossref

6. Kayler DE, Lyttle D. Surgical interruption of patellar blood supply by total knee arthroplasty. Clin Orthop Relat Res 1988;(229):221-7. Crossref

7. Insall JN, Easley ME. Surgical techniques and instrumentation in total knee arthroplasty. In: Insall JN, Scott WN, editor. Surgery of the Knee, 3rd ed. New York: Churchill Livingstone; 2001. p.1553-620.
8. Insall J. A midline approach to the knee. J Bone Joint Surg Am 1971;53(8):1584-6. Crossref

9. Keating EM, Faris PM, Meding JB, Ritter MA. Comparison of the midvastus muscle-splitting approach with the median parapatellar approach in total knee arthroplasty. J Arthroplasty 1999;14(1):29-32. Crossref

10. Vince KG. Subvastus approach. In: Scuderi GR, Tria AJ, editors. Surgical Techniques in Total Knee Arthroplasty, 1st ed. New York: Springer; 2002. p.119-26. Crossref

11. Ritter MA, Keating EM, Faris PM. Clinical, roentgenographic, and scintigraphic results after interruption of the superior lateral genicular artery during total knee arthroplasty. Clin Orthop Relat Res 1989;(248):145-51. Crossref

12. Hofmann AA, Plaster RL, Murdock LE. Subvastus (Southern) approach for primary total knee arthroplasty. Clin Orthop Relat Res 1991;(269):70-7. Crossref

13. Engh GA, Ammeen DJ. The midvastus approach to the knee.J Knee Surg 2003;16(1):48-51. https://pubmed.ncbi.nlm.nih. gov/12568267/

14. Bramlett $\mathrm{KW}$, Haller WN, Krauss WD. The trivector retaining approach. In: Scuderi GR, Tria AJ, editors. Surgical Techniques in Total Knee Arthroplasty, 1st ed. New York: Springer; 2002. p.131-6. Crossref

15. Keblish PA. The lateral approach for the total knee arthroplasty. J Knee Surg 2003;16:62-8. https://pubmed. ncbi.nlm.nih.gov/12568271/

16. Garvin KL. Quadriceps snip. In: Scuderi GR, Tria AJ, editors. Surgical Techniques in Total Knee Arthroplasty, 1 st ed. New York: Springer; 2002. p.149-54. Crossref

17. Callaghan JJ, Windsor RE. V-Y quadricepsplasty. In: Scuderi GR, Tria AJ, editors. Surgical Techniques in Total Knee Arthroplasty, 1st ed. New York: Springer; 2002. p.155-8. Crossref

18. Dolin MG. Osteotomy of the tibial tubercle in total knee replacement. A technical note. J Bone Joint Surg Am 1983;65(5):704-6. Crossref 
19. Gooding CR, Garbuz DS, Masri BA. Extensile surgical exposures for revision total knee replacement. In: Scott WN, Insall JN, editor. Surgery of the Knee, 5th ed. Philadelphia: Elsevier / Churchill Livingstone; 2012. p.1320-6. Crossref

20. Laskin RS. Soft tissue balancing of the varus knee. In: Callaghan JJ, Rosenberg GA, Rubash HE, Simonian PT, Wickiewicz TL, editors. The Adult Knee, 1st ed. Philadelphia: Lippincott Williams \& Wilkins; 2003. p.1217-22.

21. Matsueda M, Gengerke TR, Murphy M, Lew WD, Gustilo RB. Soft tissue release in total knee arthroplasty. Cadaver study using knees without deformities. Clin Orthop Relat Res 1999;366:264-73. Crossref

22. Buechel FF. A sequential three-step lateral release for correcting fixed valgus knee deformities during total knee arthroplasty. Clin Orthop Relat Res 1990;260:170-5. Crossref

23. Bellemans J, Vandenneucker $\mathrm{H}$, Van Lauwe J, Victor J. A new surgical technique for medial collateral ligament balancing: multiple needle puncturing. J Arthroplasty 2010;25(7):1151-6. Crossref
24. McMahon MS, Scuderi GR, Glashow JL, Scharf SC, Meltzer LP, Scott WN. Scintigraphic determination of patellar viability after excision of infrapatellar fat pad and/or lateral retinacular release in total knee arthroplasty. Clin Orthop Relat Res 1990;260:10-6. Crossref

25. Worland RL, Jessup DE, Johnson J. Posterior cruciate recession in total knee arthroplasty. J Arthroplasty 1997;12(1):70-3. Crossref

26. Burke DW, O'Flynn H. Primary total knee arthroplasty. In: Chapman MW, editor. Chapman's Orthopaedic Surgery, 3rd ed. Lippincott Williams \& Wilkins, 2001. p.2869-95.

27. Scuderi GR, Tria AJ. Techniques in total knee and revision arthroplasty. In: Scuderi GR, Tria AJ, editors. Knee Arthroplasty Handbook, 1st ed. New York: Springer; 2006. p.1-22. Crossref 